\title{
Archeologia dell'architettura e rappresentazione digitale: procedure e strumenti tra connessioni e intersezioni
}

\author{
Ilaria Trizio \\ Francesca Savini \\ Andrea Ruggieri
}

Abstract

La ricerca illustrata in questo contributo descrive l'esperienza portata avanti da un team multidisciplinare per l'analisi del costruito storico con un particolare approfondimento alla problematica, oggi molto dibattuta, della rappresentazione tridimensionale dei manufatti finalizzata all'analisi, alla gestione e allo scambio dei dati. Infatti, le possibilità offerte dalle ICT sono molteplici e vanno dai modelli fotogrammetrici con la visualizzazione dell'analisi stratigrafica 3D alla gestione di mesh in ambenti GIS 3D e in Sistemi Informativi, dalla modellazione parametrica del patrimonio architettonico (HBIM) alla realtà virtuale per la divulgazione e l'interpretazione dei dati.

Obiettivo preminente della ricerca è quello di definire procedure che, a partire dal rilievo digitale dei manufatti e dalla generazione di modelli semantici tridimensionali, favoriscano la documentazione e lo scambio dei dati tra le diverse figure professionali che a vario titolo sono chiamate in causa nel processo di conoscenza, gestione, conservazione e valorizzazione del patrimonio architettonico e archeologico. Con la sperimentazione è stato messo a punto di uno strumento digitale capace di sintetizzare, in un unico ambiente virtuale, le varie esigenze di documentazione coniugando i dati sullo stato di conservazione del bene con i risultati delle analisi archeologiche, storico-artistiche e documentali di un complesso architettonico abbaziale pluristratificato.

\section{Parole chiave}

documentazione del patrimonio architettonico, rappresentazione tridimensionale, archeologia dell'architettura, interdisciplinarietà, realtà virtuale.
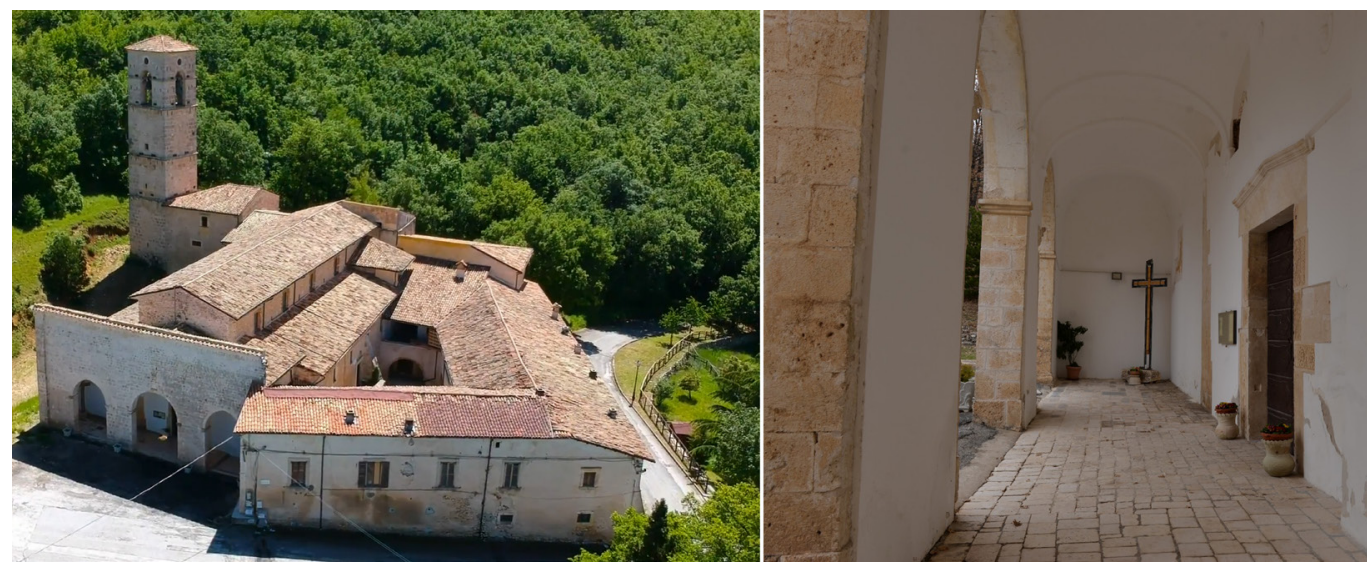


\section{La rappresentazione digitale dell'analisi archeologica dei manufatti architettonici}

Per mettere a sistema i risultati delle analisi multidisciplinari finalizzate all'approfondita conoscenza dei manufatti architettonici e archeologici, la ricerca si orienta sempre più all'utilizzo di tecnologie digitali che integrano i dati geometrici e materici della struttura con i risultati dell'analisi storica e archeologica condotta sulle murature.

Le possibilità offerte dalle ICT sono molteplici e vanno dalla produzione di modelli fotogrammetrici [Bianconi, Filippucci 20 I9; Bertocci et al. 2019] alla messa a punto dell'analisi stratigrafica tridimensionale attraverso l'elaborazione e il post-processamento di modelli digitali [Trizio et al. 20 I7; Drap et al. 20 I7]. Alla stessa sfera attiene la gestione di mesh in ambenti GIS 3D con il collegamento topologico dei dati al modello [Dell'Unto 20 I 6; Dell'Unto et al. 2016; Landeschi, 20 I8] e la creazione di Sistemi Informativi finalizzati al restauro dei beni [Apollonio et al. 2018] o alle ipotesi di evoluzione diacronica di ciascun sito [Trizio et al. 2019a]. Una ulteriore spinta rispetto ai risultati ottenuti con la mappatura digitale dei modelli fotogrammetrici viene dal ricorso alla modellazione parametrica dei manufatti sui quali si visualizza la lettura stratigrafica tridimensionale [Arrighetti et al. 20 I9; Trizio et al. $2019 b]$. Infine, sono in corso di sperimentazione applicazioni volte a documentare, gestire e diffondere i dati di scavo [Garagnani et al. 20 I6;Vecchione et al. 20 I 9], o per la divulgazione e interpretazione dei risultati dell'analisi archeologica [Pietroni 2020].

Sebbene le tecnologie digitali vengano intensivamente utilizzate a tale scopo, grazie anche ai diversi software free e open source [Ausonio et al. 2018], un passo ulteriore dovrebbe essere orientato all'individuazione di piattaforme o ambienti digitali, anche immersivi, in grado di raccogliere e gestire i molteplici dati scaturiti dalle complessità tipiche del palinsesto rappresentato dagli edifici storici [Trizio et al. 2019c], la cui analisi stratigrafica porta a produrre una notevole quantità di informazioni eterogenee da correlare alla rappresentazione grafica, possibilmente tridimensionale, del bene.

Fig. I.Veduta da drone dell'abbazia di San Giovanni Battista di E.M. Manieri, 20।8).

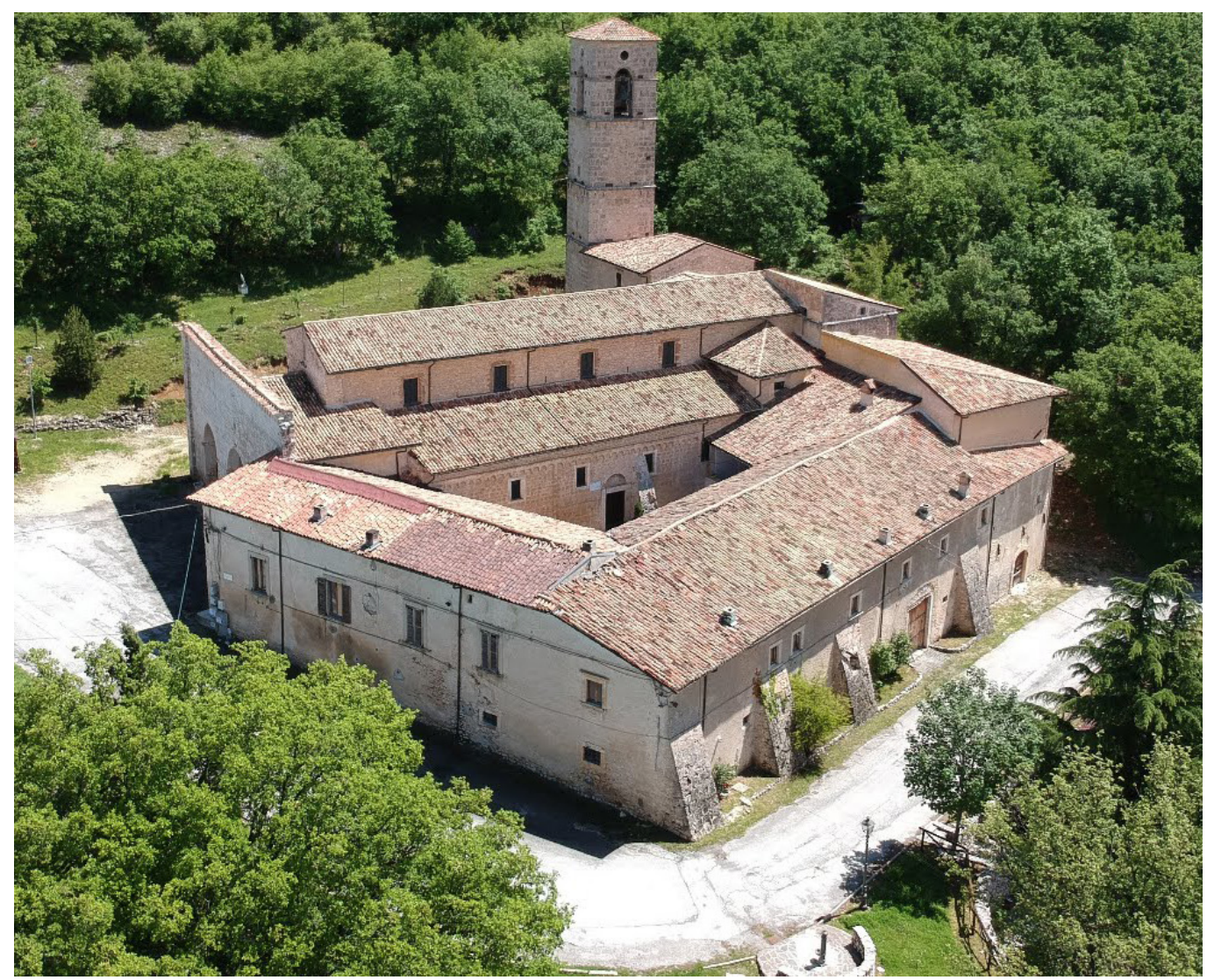




\section{Le metodologie d'indagine e gli strumenti}

La conoscenza approfondita e l'appropriata documentazione, anche digitale, dei manufatti architettonici che costituiscono il nostro patrimonio sono concetti ribaditi di frequente in numerose sedi, e diventano cruciali in relazione a quei contesti in cui il rischio di perdita dei beni, dovuto a eventi naturali e/o antropici, è spiccato. Operando nel delicato momento della ricostruzione post sismica del territorio aquilano, il gruppo coinvolto nella ricerca descritta in queste pagine sta mettendo a punto delle procedure che, attraverso la rappresentazione digitale, garantiscano un'efficace gestione dei dati derivati dalle analisi diagnostiche, archeologiche e storico-artistiche finalizzate a incrementare la conoscenza del patrimonio e propedeutiche ai progetti di restauro.

Ai classici metodi d'indagine per l'acquisizione dei dati (rilievi geometrici, ricerche sull'edito, analisi delle fonti d'archivio e delle relazioni tecniche scaturite da studi pregressi ecc.) vengono affiancate metodiche più puntuali mirate ad approfondire la conoscenza (analisi metriche e tipologiche, analisi diagnostiche per lo stato di conservazione, studio critico degli apparati iconografici e decorativi, analisi stratigrafiche delle murature ecc.) mettendo in campo una cooperazione tra le diverse expertises di ricercatori e professionisti coinvolti.

Fig. 2. Particolari dell'ingresso dell'abbazia e del cortile con l'evidenza della successione degli nterventi effettuati nel tempo e delle superfetazioni architettoniche.
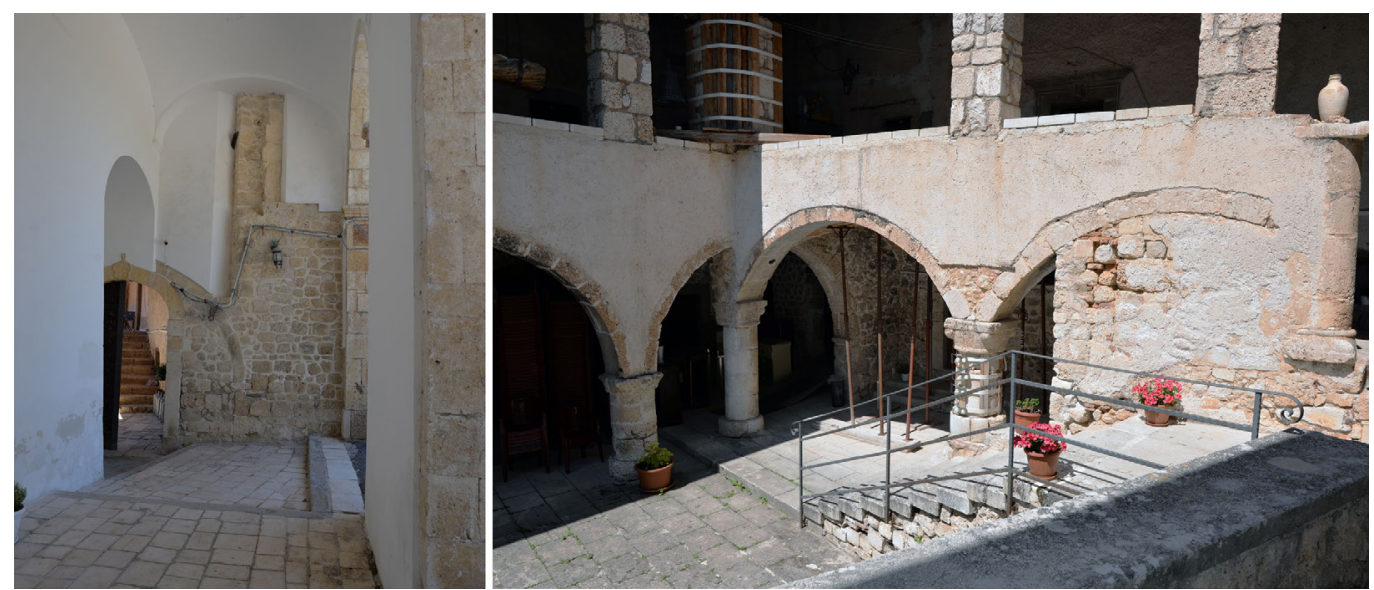

Nel corso degli anni, particolare attenzione è stata riservata all'esame delle problematiche legate all'analisi stratigrafica tridimensionale di contesti architettonici e archeologici in ambienti digitali attraverso lo sviluppo di modelli sui quali sono state mappate le Unità Stratigrafiche Murarie (USM), fruibili in formato pdf attivando il contenuto 3D [Marchetti et al. 20 I7], la realizzazione di GIS 3D a partire da mesh fotogrammetriche [Trizio et al. 20 I9a] e la modellazione parametrica dell'architettura con la realizzazione di HBIM [Continenza et al. 20 I 8; Trizio, Savini, Giannangeli 20 I 8; Brusaporci et al. 20 I 8; Trizio et al. 20 I9b].

Parallelamente, in collaborazione con ricercatori dell'Università degli Studi dell'Aquila e liberi professionisti, si stanno sperimentando sistemi in realtà virtuale per la gestione dei modelli fotogrammetrici e delle informazioni a essi collegate [Trizio et al. 20 I 8], per la ricostruzione di architetture scomparse o modificate nel tempo, rese visibili attivando delle timeline [Trizio et al. $2019 \mathrm{~d}$ ] e alternative più smart per la realizzazione di modelli navigabili realizzati con foto a $360^{\circ}$ [Trizio et al. 2019c].

Questi ultimi sistemi digitali di realtà virtuale garantiscono tanto la conservazione e gestione dei dati collegati alla rappresentazione del manufatto grazie all'aggiunta di contenuti (testi, immagini o audio), quanto la fruizione delle informazioni planivolumetriche, anche tridimensionali, grazie a collegamenti a piattaforme online che permettono di esplorare i modelli fotogrammetrici e le nuvole di punti (Sketchfab, 3DHOP ecc.). 
Per testare le potenzialità di questo sistema è stata intrapresa la sperimentazione sull'abbazia di San Giovanni a Collimento di Lucoli, L'Aquila (fig. I), un complesso dalla lunga e stratificata storia che ha subito danni con il sisma del 2009 e, poiché non è ancora del tutto restaurato, si presta a integrare gli strumenti della conoscenza e i saperi delle diverse figure professionali coinvolte.
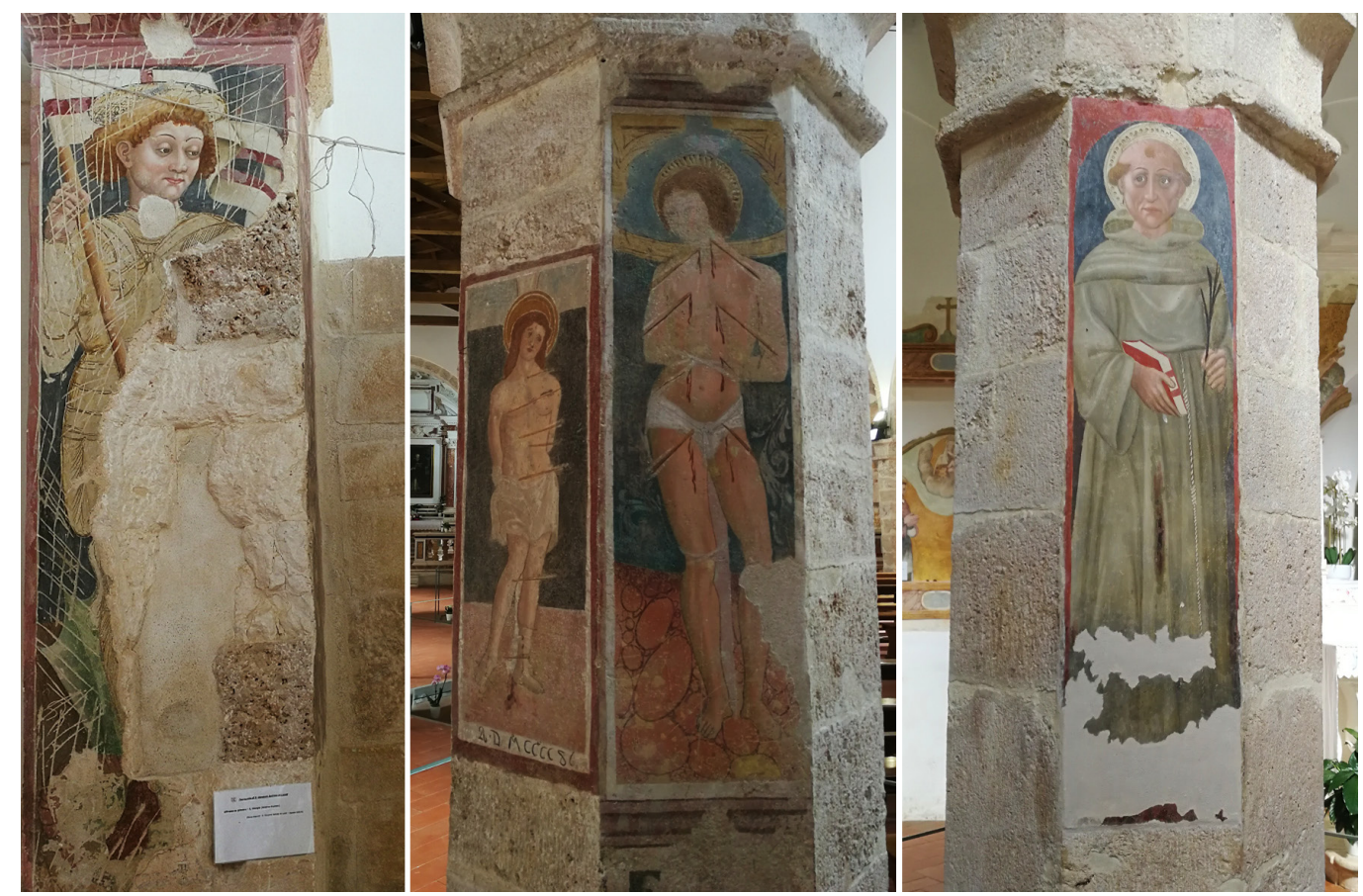

\section{Il Caso di studio: l'abbazia di San Giovanni a Collimento di Lucoli (AQ)}

L'abbazia di San Giovanni è ubicata nel territorio di Lucoli (AQ), comune sparso di montagna dalla storia insediativa lunga e interconnessa con quella dell'Aquila in quel particolare legame città-contado che ha caratterizzato quest'ultima fin dalla sua nascita. La prima attestazione dell'abbazia risale al 1077 (Muratori I74I), data in cui Odorisio, conte dei Marsi, la fonda ex novo dopo il suo trasferimento nella sua residenza di Collimento, in linea con le pratiche di sviluppo delle signorie rurali sul territorio [Marcotulli 2008]. II potere del complesso, situato in un punto strategico, accresce negli anni, come attestato dall'accuratezza ancora leggibile dell'edilizia ecclesiastica e abbaziale, sebbene la continuità d'uso del sito e i continui ampliamenti abbiano compromesso significativamente l'originalità dell'impianto. L'importanza dell'abbazia è sottolineata anche dal ruolo che ebbe nella nuova fondazione della città dell'Aquila, ad opera degli angioini. È noto infatti che il capoluogo abruzzese venne edificato dagli abitanti dei castelli del contado ai quali fu assegnato, all'interno delle mura urbiche, uno spazio chiamato 'locale' nel quale insediarsi e costruire, oltre all'edilizia civile, una chiesa per ciascun sito di provenienza. Quella di Lucoli fu intitolata a San Giovanni, in onore dell'antica abbazia extra civitatem, e divenne così importante da dare il nome a uno dei quattro 'quarti' in cui è divisa L'Aquila e da ricoprire il ruolo di chiesa 'capoquarto'. A differenza della chiesa cittadina che comincia a perdere la sua importanza cedendo il titolo di collegiale a San Marciano [Antonini 1988], il complesso abbaziale di San Giovanni Battista di Lucoli mantiene la sua rilevanza per tutto il medioevo e oltre a interessanti interventi costruttivi realizzati fra il XIII e il XIV secolo [Marcotulli 2009] vien arricchita con opere decorative in epoca moderna [Mancini 200I]. 
Fig. 4. Nuvola di punti de complesso architettonico ottenuta con rilievo lase scanner.
II complesso attualmente è costituito da diversi corpi di fabbrica sovrapposti e affiancati, risultato di una serie di modifiche costruttive, ampliamenti, ripensamenti e restauri dovuti in buona parte ai terremoti storici e contemporanei (fig. 2).

Un ruolo fondamentale nella conformazione attuale dell'abbazia è da attribuire all'importante intervento condotto sul finire del XX secolo [Mancini 200 I] sulla chiesa abbaziale oggetto di un vivace dibattito scientifico sul tema del restauro [Bartolomucci 20 I6]. La scelta di portare alla luce l'apparato decorativo a scapito di quello architettonico, ha portato alla rimozione delle superfetazioni più moderne per valorizzare gli affreschi medievali (fig. 3), alcuni dei quali attribuiti ad Andrea de Litio [Japadre 2007]. Dopo un'attenta analisi del materiale edito prodotto durante la fase di restauro degli anni '90 [Pansa 1996; Mancini 200 I] e di quello derivante da un progetto di dottorato di archeologia leggera intrapreso nell'anno accademico 2006/2007 [Marcotulli 2008; 2009; 20 I0; 20 I I], è stata approntata un'indagine conoscitiva del manufatto attraverso la ricerca archeologica, quella storico-artistica e l'analisi sullo stato di conservazione, condotta sia sul campo che in remoto sul modello digitale ottenuto attraverso il rilievo integrato (figg. 4, 5).

Le indagini diagnostiche non invasive sono state finalizzate alla comprensione dello stato di conservazione degli intonaci e delle strutture, mentre l'analisi archeologica degli elevati è stata orientata alla convalida dei dati editi in precedenza poiché la lettura stratigrafica risultava particolarmente difficoltosa a causa, oltre che del restauro degli anni '90, dagli interventi più recenti effettuati in seguito all'ultimo sisma, che hanno reso uniforme e poco leggibile la muratura.

I dati, ottenuti dall'incrocio delle procedure e dei lessici delle varie discipline coinvolte (studio delle fonti; analisi stratigrafica delle murature; stato di conservazione dei paramenti; analisi del degrado; analisi critica dell'apparato decorativo), sono stati analizzati e rielaborati con i lessici del disegno e della rappresentazione digitale (fig. 6).

Per la fruizione, gestione e scambio dei dati e la valorizzazione del complesso architettonico è stato realizzato un sistema digitale navigabile, un vero e proprio tour virtuale del complesso abbaziale, ottenuto con il software 3DVista che offre anche un servizio di hosting per la visualizzazione e condivisione del prodotto virtuale.

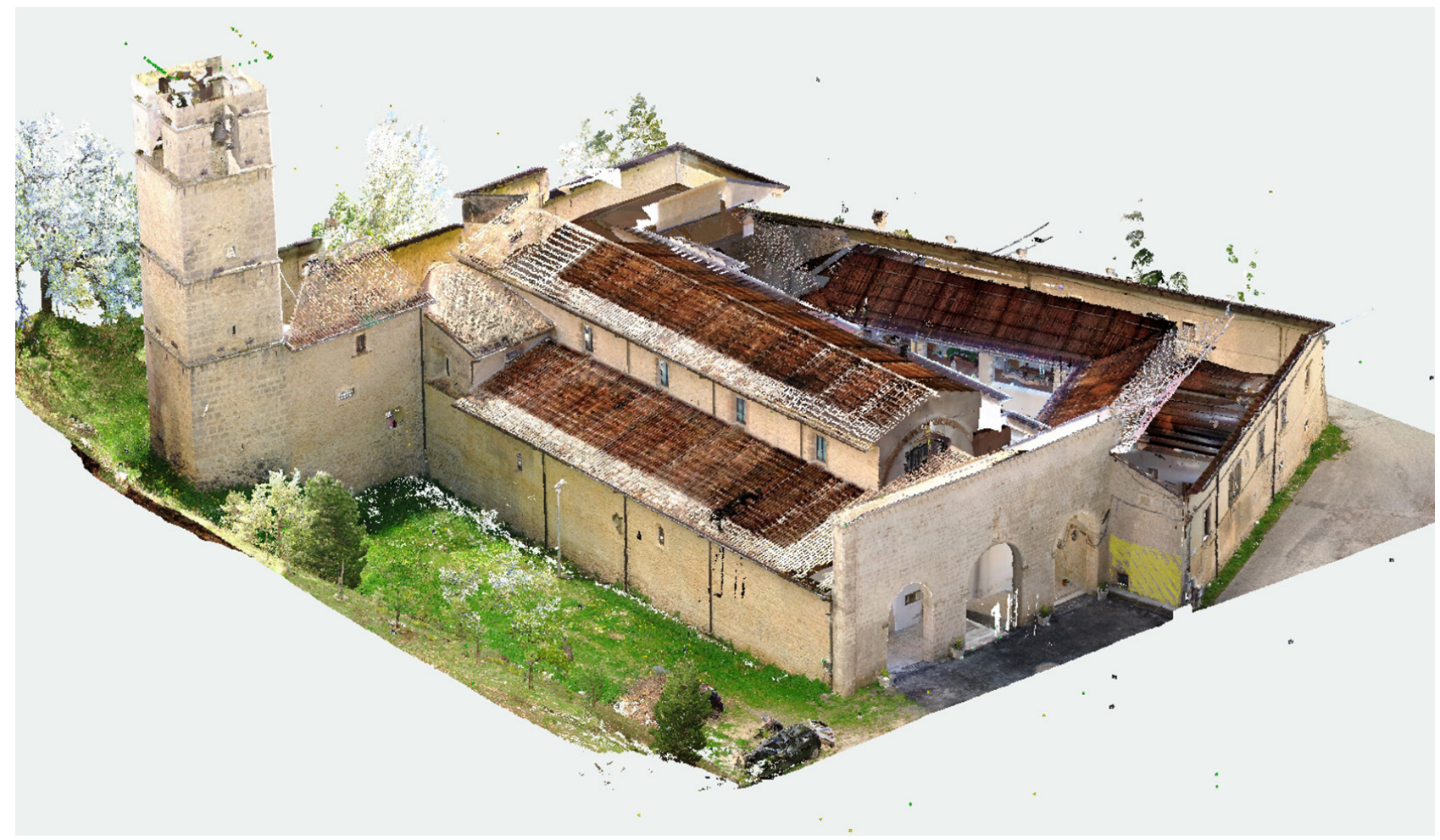




\section{Dal rilievo strumentale al VR}

II rilievo del complesso abbaziale, ottenuto con la classica integrazione di procedure laser scanning (Laser scanner Faro Focus S70) e fotogrammetriche (Agisoft Metashape Professional I.5. I), è stato implementato a partire dall'elaborazione dei risultati dell'analisi archeologica esplicitati all'interno di un modello semantico con texture fotorealistiche ad alta risoluzione. La procedura ha previsto l'editing degli ortofotopiani esportati dal modello fotogrammetrico con la mappatura delle unità stratigrafiche archeologiche (USM), dei segni degli interventi di restauro moderni, del degrado visibile sulle murature.

La generazione di un nuovo modello tridimensionale con le mappe tematiche è stata possibile ritexturizzando la mesh poligonale (fig. 7) all'interno del software MeshLab (release v 1.3.2), fruibile in formato pdf3D, il quale consente la visualizzazione e l'interrogazione 3D del modello grazie ai tools di un comune Adobe Reader.

Parallelamente, è stato progettato un ambiente VR capace di racchiudere e di conservare in un'unica piattaforma i dati scientifici prodotti e divulgarli ad un pubblico più ampio assurgendo a strumento di valorizzazione del bene (fig. 8).

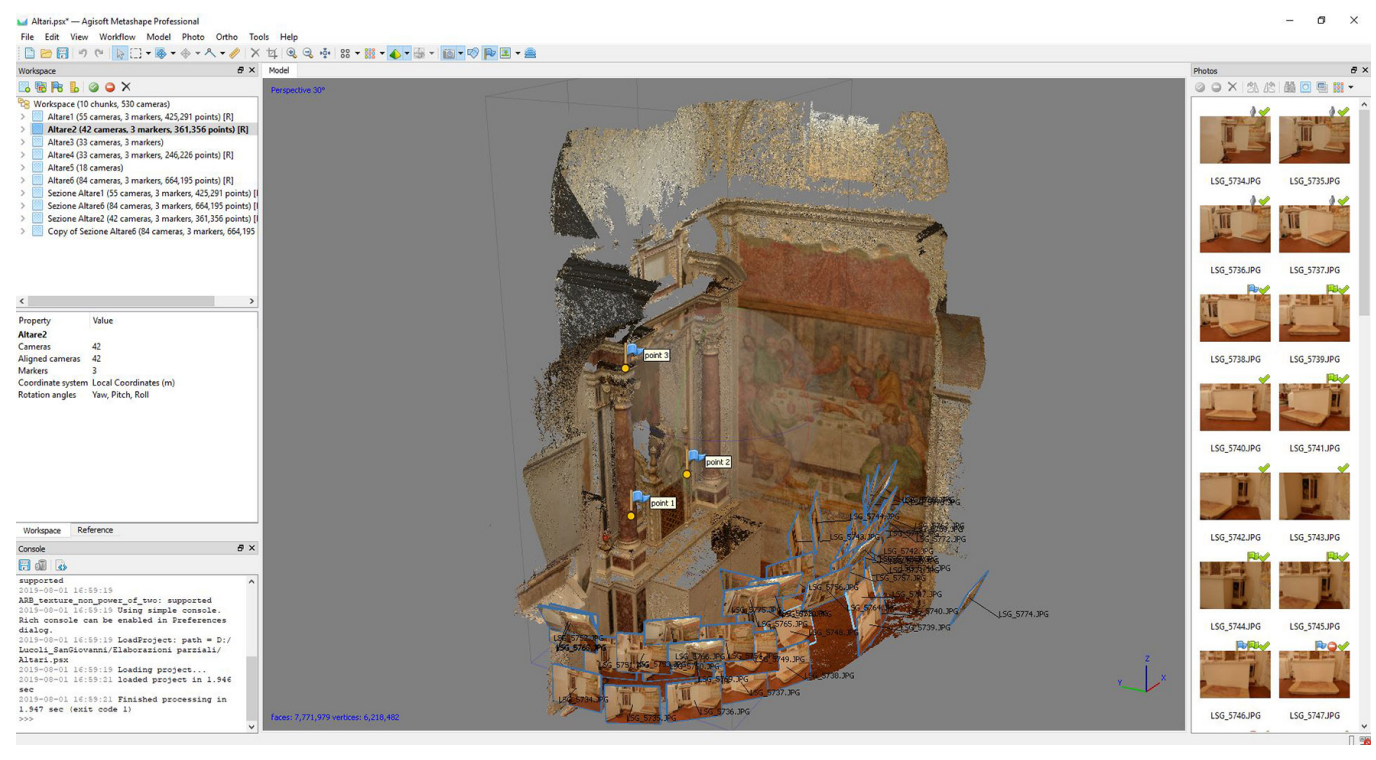

II tour virtuale è stato realizzato a partire dalle immagini equirettangolari ricavate per ogni punto di presa della stazione laser durante l'acquisizione delle nuvole. Le immagini, dopo essere state editate nelle dimensioni con un programma di grafica 2D, sono state collegate tra loro in modo da creare un percorso guidato alla scoperta dell'abbazia. A dei punti d'interesse (POI) collocati all'interno e all'esterno dell'edificio sono state agganciate le informazioni che rielaborano in chiave divulgativa i risultati della ricerca scientifica; grazie a contenuti testuali e audio è possibile ottenere informazioni temporali, materiali, strutturali, ambientali, economiche e culturali legate alla storia dell'abbazia di San Giovanni. Anche all'interno di questo ambiente, attivando appositi hotspot, è possibile visualizzare le murature mappate con l'analisi archeologica, con il degrado delle superfici (figg. 9, I0) e i contenuti iconografici che mostrano la chiesa prima e dopo l'intervento di restauro (fig. I I).

II sistema VR realizzato, oltre a fornire l'accesso alle informazioni, aumentando la conoscenza del patrimonio culturale, incrementa l'accessibilità al bene da parte di un pubblico ampio attraverso la possibilità di una visita virtuale, interattiva e innovativa. L'opportunità di navigare lo spazio digitale, in modalità desktop o immersiva con cardboard o VR box, pone il fruitore 


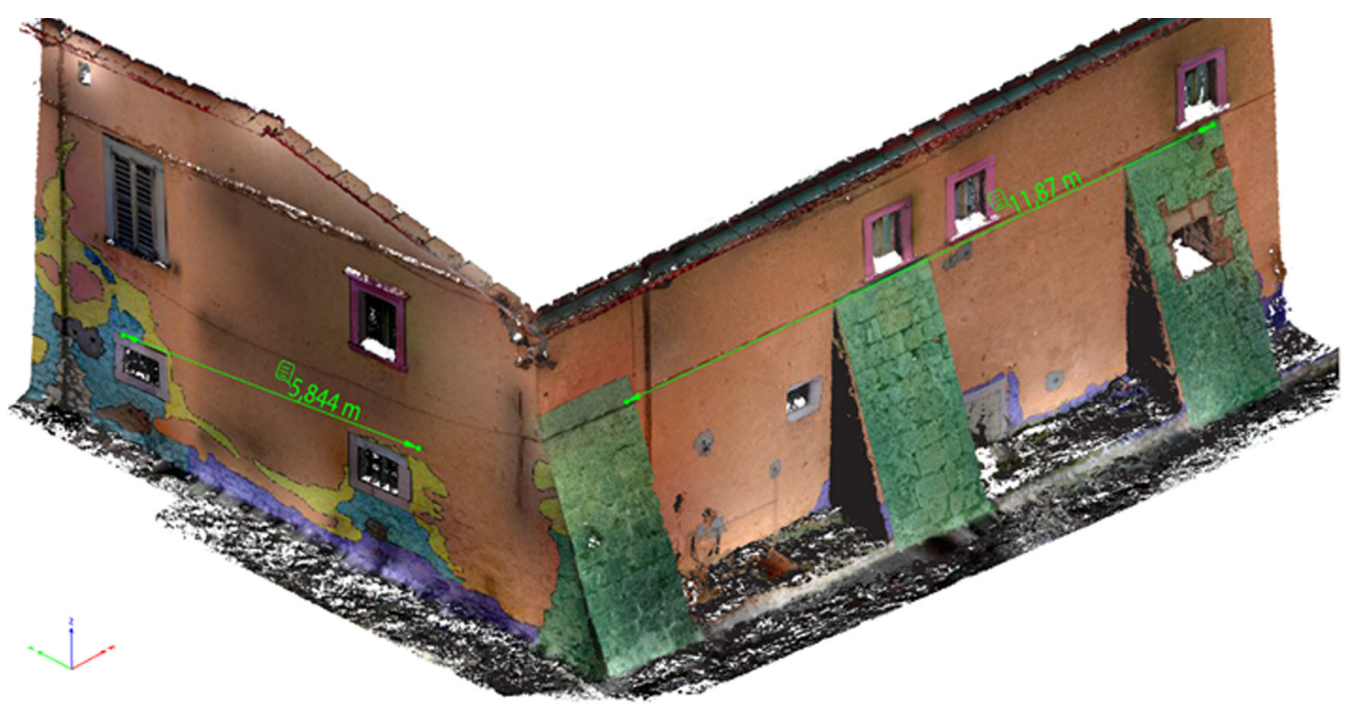

Fig. 7.Visualizzazione di alcuni passaggi della procedura utilizzata per la semantico con il software Meshlab.
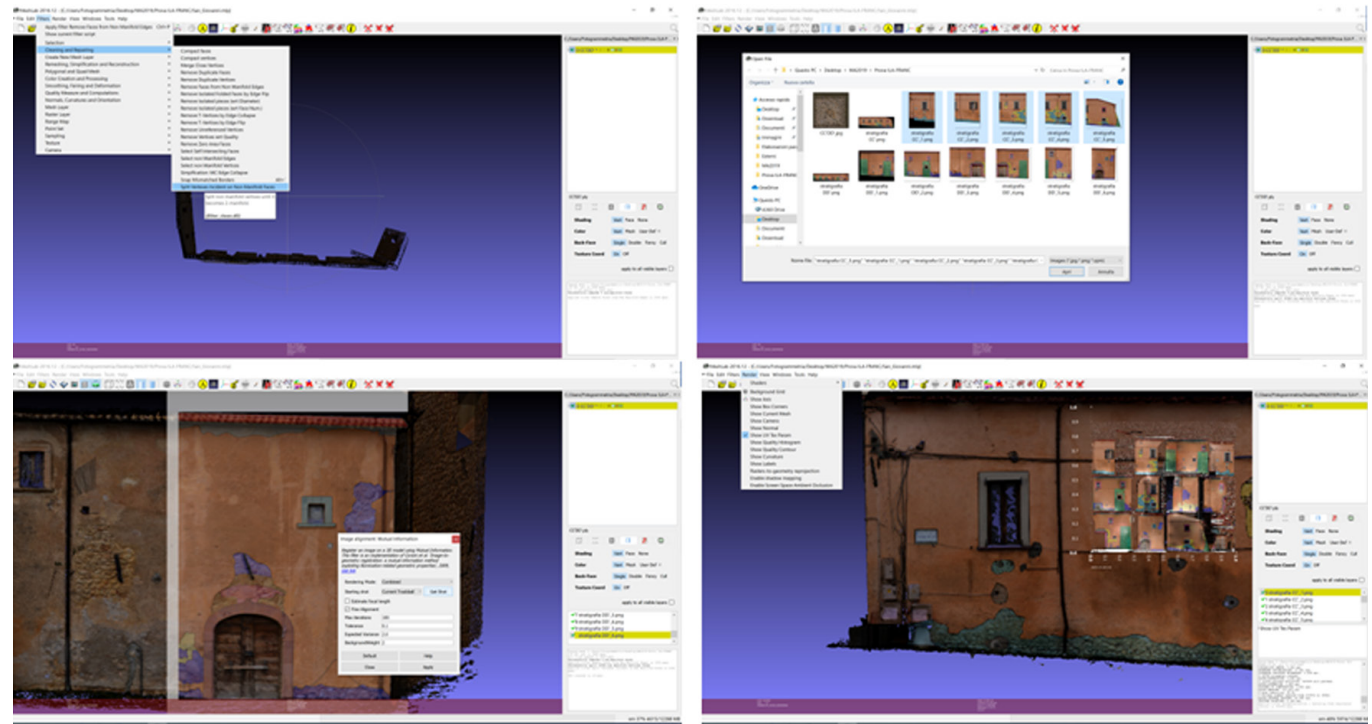
Fig. 8. Sistema VR dell'abbazia per la condivisione dei dati e la valorizzazione del patrimo

Fig. 9. Modello VR che permette la fruizione dei risultati dell'analisi stratigrafica delle murature.
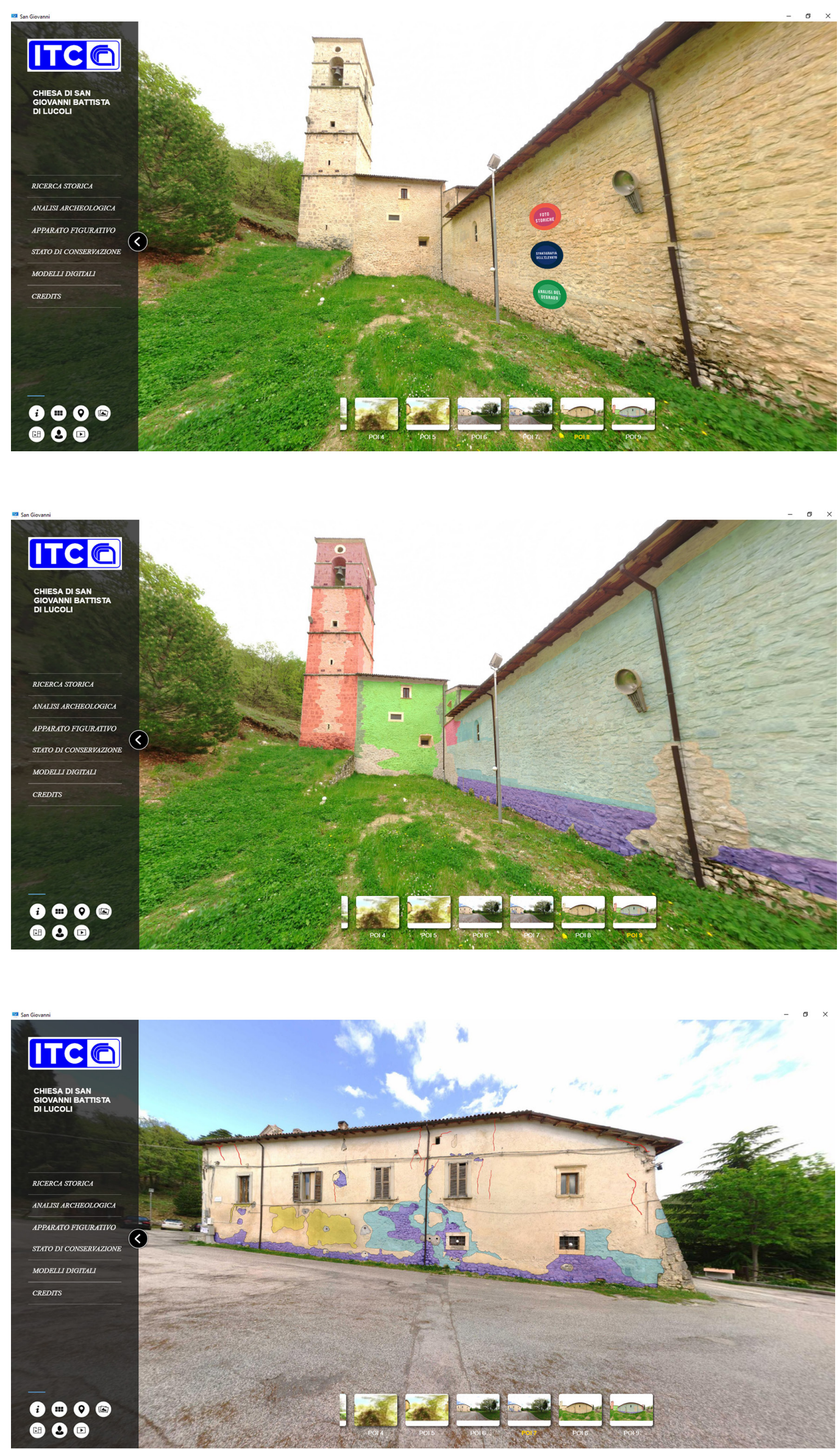
al centro della scena permettendo di godere appieno del bene sia dal punto di vista tecnico (per l'analisi del manufatto e lo scambio di dati tra professionisti) sia dal punto di vista culturale, incrementando parallelamente l'offerta turistica del territorio.

\section{Conclusioni e prospettive future}

Le diverse sperimentazioni condotte sul territorio in concomitanza con la ricostruzione post sismica hanno evidenziato le potenzialità dei sistemi di rappresentazione digitale per la gestione, l'analisi e lo scambio dei dati scientifici tra le varie figure professionali coinvolte nel processo di conoscenza e recupero del patrimonio.

I sistemi in realtà aumentata, realtà virtuale e realtà mista che il team di ricerca sta testando sono volti a facilitare la documentazione, l'archiviazione e lo scambio di dati oltre ad essere efficaci strumenti per la connessione dei manufatti del patrimonio culturale contribuendo alla loro valorizzazione nell'ottica di una migliore fruizione turistica. Parallelamente allo sviluppo dei sistemi digitali e alle sperimentazioni finalizzate all'utilizzo dei modelli fotogrammetrici con la Realtà Virtuale, il team sta affrontando e intende approfondire la problematica dell'integrazione di modelli parametrici HBIM con la Realtà Virtuale, utilizzando software dedicati allo sviluppo di videogiochi, che ben si prestano alla rappresentazione del Patrimonio [I].

Fig. II. Modello VR che permette la visione dello so e di quello precelesso e di quello precedente allintervento di restauro degli anni ' 90 del secolo scorso.

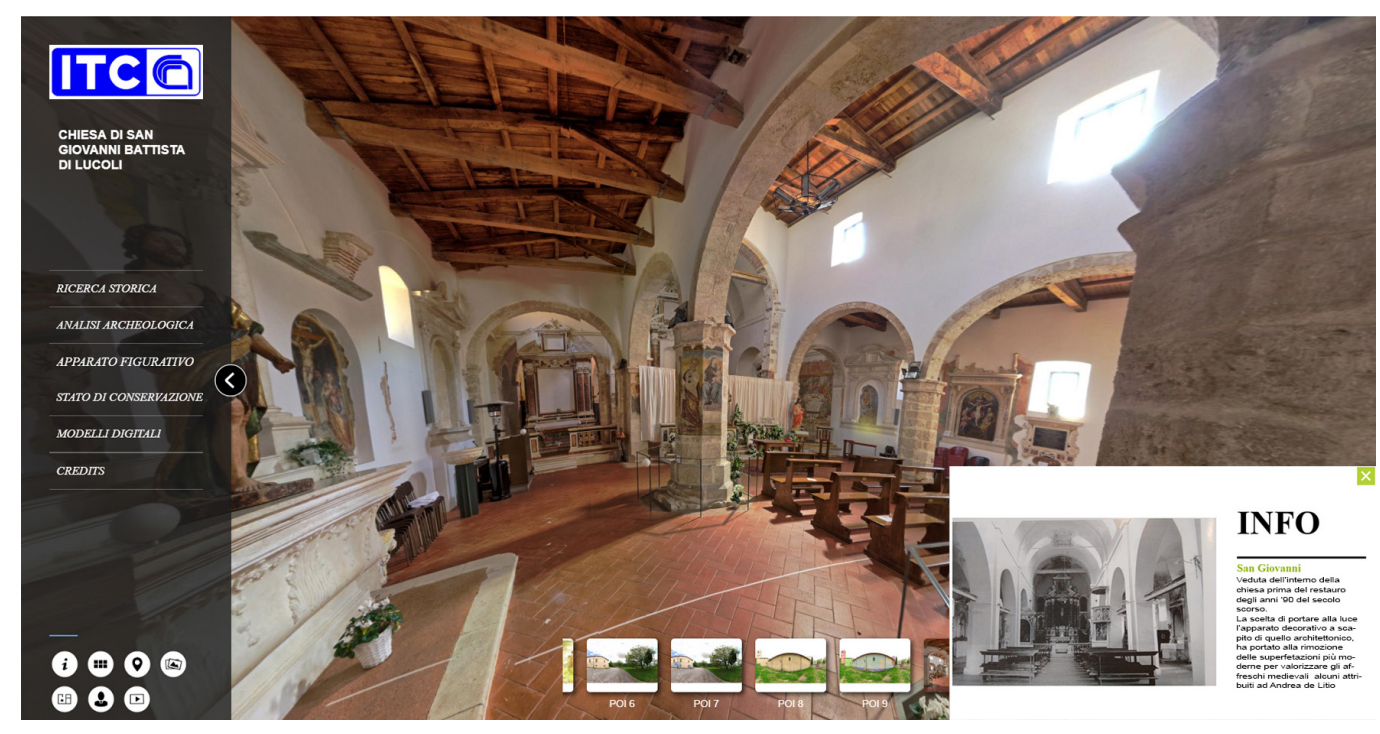

Note

[I] Crediti dell'articolo: sebbene il contributo sia stato concepito unitariamente dagli autori, si attribuiscono a llaria Trizio i paragrafil e 2, a Francesca Savini i paragrafi 3 e 4 e ad Andrea Ruggieri il rilievo laser del complesso architettonico e l'estrapolazione delle immagini equirettangolari. Si ringraziano Alessandro Giannangeli per la realizzazione del modello fotogrammetrico e Alessio Cordisco per la realizzazione del sistema digitale fruibile in Realtà Virtuale.

Riferimenti bibliografici

Antonini Orlando (1988). Architettura religiosa aquilana. L'Aquila: Edizione del Gallo Cedrone.

Apollonio Fabrizio Ivan, Basilissi Vilma, Callieri Marco et. al. (2018). 3D-centered information system for the documentation of a complex restoration intervention. In Journal of Cultural Heritage, 29, 201 8, pp. 89-99.

Arrighetti Andrea, Pancani Giovanni, Gentili Marta (2019). La Pieve di Santa Maria a Buiano in Casentino. Rilievo, lettura archeologica e H-BIM delle architetture. In Archeologia dell'Architettura. XXIV, 20 I9, pp. I57- 176.

Ausonio Elena, Battini Carlo, Fagandini Roberta et al. (2019). Potenzialità dei software Free e/o Open Source per la modellazione, gestione e fruizione di entità 3D. In Geomatics Workbooks, n I4, pp. 4-20. Roma: FOSS4G-it. 
Bartolomucci Carla (2016). La dialettica tra eresie e ortodossie nei restauri in Abruzzo, dagli anni Sessanta all'attuale 'ricostruzione' post sismica. In Biscontin Giovanna, Driussi Guido (a cura di). Eresia e ortodossia nel restauro: progetti e realizzazioni. Atti del 32 Convegno Internazionale Scienza e Beni Culturali. Bressanone, 28 giugno-I luglio 20 I6. pp. 683-693. Venezia: Arcadia Ricerche.

Bertocci Stefano,Arrighetti Andrea, Bigongiari Marco (2019). Digital Survey for the Archaeological Analysis andthe Enhancement of Gropina Archaeological Site. In Heritage 2, 2019 , pp. 848-856.

Bianconi Fabio, Filuppucci Marco (2019). La fotomodellazione per il rilievo archeologico. In Archeologia e Calcolatori, 30, 20।9, pp. 205-228.

Brusaporci Stefano, Trizio Ilaria, Ruggieri Gianfranco et al. (20I8). AHBIM per l'analisi stratigrafica dell'architettura storica. In Restauro Archeologico, 27, 2018, n. I, pp. II2-131.

Continenza Romolo, Redi Fabio, Savini Francesca et al. (2018). HBIM for the Archaeology of Standing Buildings: Case Study of the Church of San Cipriano in Castelvecchio Calvisio (L'Aquila, Italy). In Fogliaroni Paolo, Ballatore Andrea, Clementini Eliseo (eds). Proceedings of Workshops and Posters at the 13th International Conference on Spatial Information Theory. COSIT 2017. Lecture Notes in Geoinformation and Cartography. 315-323 pp. Cham: Springer.

Dell'Unto Nicolò, Landeschi Giacomo, Leander Touati Anne-Marie et al. (2016). Experiencing Ancient Buildings from a 3D GIS Perspective: a Case Drawn from the Swedish Pompeii Project. In Journal of Archaeological Method and Theory, 23, Issue I, pp. 73-94.

Dell'Unto Nicolò (20 I 6). Using 3D GIS Platforms to Analyse and Interpret the Past. In Forte Maurizio, Campana Stefano (eds). Digital Methods and Remote Sensing in Archaeology. Archaeology in the Age of Sensing. pp. 305-322. Cham: Springer.

Drap Pierre, Papini Odile, Pruno Elisa, et al. (2017). Ontology-Based Photogrammetry Survey for Medieval Archaeology: Toward a 3D Geographic Information System (GIS). In Geosciences, 7, 2017, 93.

Garagnani Simone, Gaucci Andrea, Gruška Bojana (2016). From The Archaeological Record To Archaeobim: The Case Study OfThe Etruscan Temple Of Uni In Marzabotto. In Virtual Archaeology Review, 7, 5, 20 I 6, pp. 77-86.

Japadre Leonardo (2007). Guida storico-artistica dell'abbazia di san Giovanni Battista in Lucoli. L'Aquila: Japadre.

Landeschi Giacomo (2018). Rethinking GIS, three-dimensionality and space perception in archaeology. In World Archaeology, maggio, 2018, pp. 17-32.

Mancini Renzo (200 I). San Giovanni Battista di Lucoli. Storia, cronologia, restauro. L'Aquila: Japadre.

Marchetti Alessio, Redi Fabio, Savini Francesca et al. (2017). La chiesa di San Cipriano a Castelvecchio Calvisio (AQ) nella Baronia di Carapelle: documentazione speditiva e analisi stratigrafica 3D del manufatto. In Archeologia dell'Architettura, XXII, 2017, pp. 239-253.

Marcotulli Chiara (2008). II conte e l'abate. Incastellamento comitale e trasferimento dei poteri sui monti di Lucoli (Aq) da un'indagine di archeologia 'leggera'. In Temporis Signa, Rivista di archeologia della tarda antichità e del medioevo, III, 2008, pp. |17-139.

Marcotulli Chiara (2009). Lo viscovo e lo abbate, ... ambo con le mitre, stavano cantu lato. San Giovanni Battista di Collimento di Lucoli dentro e fuori le mura dell'Aquila: luoghi del potere e maestranze. In Giuliano Volpe, Pasquale Favia (eds). V Congresso Nazionale di Archeologia Medievale. Foggia-Manfredonia, 30 settembre-3 ottobre 2009. pp. 767-772. Firenze: Insegna del Giglio.

Marcotulli Chiara (2010). De ecclesiis construendis: maestranze e committenti. La "rifondazione angioina" dell'Aquila e la costruzione di un'identità cittadina nella prima metà del XIV secolo. In Archeologia Medievale, XXXVII, 20 I 0, pp. 467-484.

Marcotulli Chiara (20 I I). Chiese, castelli e strategie 'baronali'. Le trasformazioni del paesaggio medievale abruzzese fra feudalità signorile e città fondata alla luce della ricerca archeologica: un caso di studio. In Ricerche Storiche, XLI, 20 I I, n. I, pp. I8I-208.

Muratori Anton Ludovico ( 174 I). Antiquitates Italicae Medii Aevii, V, Mediolani, col. 8 I 7, I 74I.

Pasqua Maurizio (1996). La chiesa di San Giovanni Battista a Collimento di Lucoli. Opus. In Quaderno di Architettura e Restauro, 5, 1996, pp. 25-56

Pietroni Eva (2020). Experiencing Past, Present, and Future Urban Environments Through Digital Representation, Storytelling, and Simulation. In Forte Maurizio, Murteira Helena (eds). DIGITAL CITIES Between History and Archaeology. New York: Oxford Univerity Press. pp. | |6- 125.

Trizio Ilaria, Savini Francesca, De Gasperis Giovanni et al. (2018). Siti perduti e inaccessibili: l'interpretazione del patrimonio attraverso applicazioni di realtà virtuale. In Salerno Rossella (a cura di). Rappresentazione materiale/immateriale. Atti del $40^{\circ}$ Convegno Internazionale dei Docenti delle Discipline della Rappresentazione, Milano I3-I 5 settembre 20 I 8. pp. 83 I-836. Roma: Gangemi Editore.

Trizio Ilaria, Savini Francesca, Giannangeli Alessandro (2018). The Building Information Modelling for the documentation of an archaeological site. International Workshop on Metrology for Archaeology and Cultural Heritage (MetroArchaeo 20 I 8), IEEE, pp. $199-205$

Trizio Ilaria, Marchetti Alessio, Redi Fabio et al. (2019a). Photogrammetric survey and 3D GIS management of mesh in the integrated investigation of complex sites. The case study of the archaeological complex of the Terme di Vespasiano at Cittaducale (RI), Italy. In Inglese Carlo, Ippolito Alfonso (eds). Conservation, Restoration and Analysis of Architectural and Archaeological Heritage. Hershey, PA: IGI Global. pp. 48-80. 
Trizio Ilaria, Savini Francesca, Giannangeli Alessandro et al. (2019b). The archaeological analysis of masonry for the restoration project in HBIM. In Int. Arch. Photogramm. Remote Sens. Spatial Inf. Sci,, XLII-2/W9, pp. 7I5-722.

Trizio Ilaria, Savini Francesca, Giannangeli Alessandro et al. (2019c). Versatil tools: digital survey and virtual reality for documentation, analysis and fruition of cultural heritage in seismic areas. In The International Archives of the Photogrammetry, Remote Sensing and Spatial Information Sciences, Volume XLII-2/W 17, 2019.6th International Workshop LowCost 3D - Sensors, Algorithms, Applications, 2-3 December 2019 , Strasbourg, France. pp. 377-384.

Trizio Ilaria, Savini Francesca, De Gasperis Giovanni et al. (2019). La navigazione VR di un'opera d'arte per la narrazione di una fabbrico storica/ VR navigation of a work of art for the tale of a historical building. In Belardi Paolo (a cura di). Riflessioni. L'arte del disegno/ll disegno dell'arte. Atti del $41^{\circ}$ Convegno Internazionale dei Docenti delle Discipline della Rappresentazione, Perugia 19-21 settembre 2019. pp. 1767- 1774. Roma: Gangemi Editore.

Vecchione Alessandro, Lureau Aurelia, Callieri Marco (2019). Gestione del dato archeologico tridimensionale via web: l'esperienza con il software 3dhop. In Archeologia e Calcolatori, 30, 2019, pp. 483-486.

\section{Autori}

Ilaria Trizio, ITC, Consiglio Nazionale delle Ricerche L'Aquila, ilaria.trizio@itc.cnr.it

Francesca Savini, Consiglio Nazionale delle Ricerche, L'Aquila, francesca.savini@itc.cnr.it Andrea Ruggieri, Università degli Studi del Molise, a.ruggieri3@studenti.unimol.it

Per citare questo capitolo:Trizio Ilaria, Savini Francesca, Ruggieri Andrea (2020). Archeologia dell'architettura e rappresentazione digitale: procedure e strumenti tra connessioni e intersezioni/Archaeology of the Architecture and Digital Representation: Procedures and Instruments between Connections and Intersections. In Arena A., Arena M., Brandolino R. G., Colistra D., Ginex G., Mediati D., Nucifora S., Raffa P. (a cura di). Connettere. Un disegno per annodare e tessere. Atti del $42^{\circ}$ Convegno Internazionale dei Docenti delle Discipline della Rappresentazione/Connecting. Drawing for weaving relationships. Proceedings of the 42th International Conference of Representation Disciplines Teachers. Milano: FrancoAngeli, pp. 282 I-2842. 


\title{
Archaeology of the Architecture and Digital Representation: Procedures and Instruments between Connections and Intersections
}

\author{
llaria Trizio \\ Francesca Savini \\ Andrea Ruggieri
}

\section{Abstract}

The research study outlined in this paper describes the experience carried out by a multisciplinary team aimed at the analysis of the built heritage, paying particular attention to an issue much debated today: the 3-dimensional representation of the artefact aimed at management and data sharing. The possibilities offered by ICT are many indeed: the photogrammetric model with $3 \mathrm{~d}$ stratigraphic analysis and the mesh management in $3 \mathrm{~d}$ GIS software as in informative systems, the parametric modelling of the architectural heritage (HBIM) and virtual reality aimed at dissemination and data interpretation. Main goal of our research study is to define workflows that - starting from the digital survey of the heritage and the development of $3 \mathrm{~d}$ semantic models - are able to support the documentation and the data sharing among the different professionals involved in the process of understanding, management, conservation and valorisation of the architectural heritage.

Through experimentation has been developed a digital tool capable of summarize - in a single virtual environment - the various needs of documentation, combining data regarding the state of conservation of the heritage with the results of the archaeological, historical-artistic and documental analyses of a multi-layered abbatial architectural complex.

Keywords

documentation of architectural heritage, three-dimensional representation, archaeology of the architecture, interdisciplinarity, virtual reality.
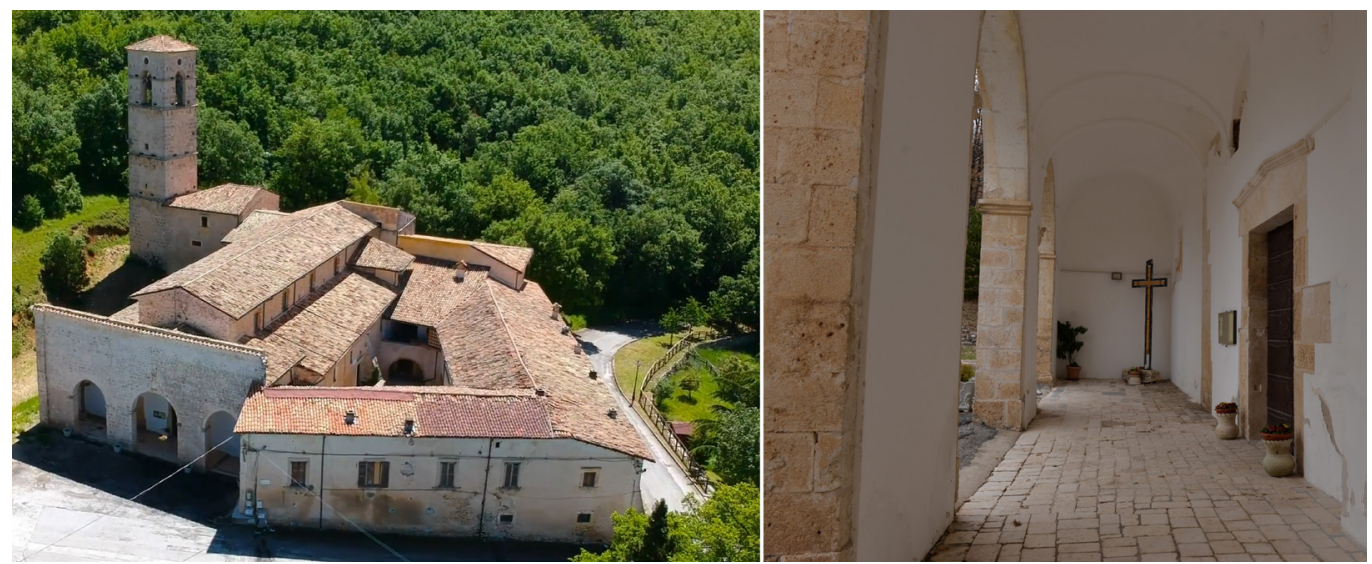


\section{The digital representation of the archaeological analysis of the architectural artifacts}

To systematize the results of the multidisciplinary analyses aimed at in-depth knowledge of the architectural and archaeological artifacts, the research is more and more directed to using digital technologies integrating the structure's geometric and materic data with the results of the historical and archaeological analysis conducted on the masonries.

The possibilities offered by ICT are several, ranging from the production of photogrammetric models [Bianconi, Filippucci 20 I9; Bertocci et al. 2019] to the development of the 3d stratigraphical analysis through processing and post-processing digital models [Trizio et al. 2017; Drap et al. 2017]. In this same framework there's the mesh management in GIS 3D environment, with the topologic link of the data to the model [Dell'Unto 2016; Dell'Unto et al. 20 16; Landeschi 20 I8] and the creation of Informative Systems aimed at the restoration of the heritage [Apollonio et al. 20 I8] or at the hypothesis of diachronic evolution of each site [Trizio et al. 2019a]. A further push regarding the results obtained from the digital mapping of the photogrammetric models is provided by the parametric modelling of the artifacts upon which is displayed the 3d stratigraphic read-out [Arrighetti et al. 2019;Trizio et al. 2019b]. Finally, are undergoing testing applications aimed at documenting, managing and spreading excavation data [Garagnani et al. 20 16; Vecchione et al. 2019], or for disclosure and interpretation of the results of the archaeological analysis [Pietroni 2020].

Although digital technologies are intensively used to that end, also thanks to the various free and open-source software [Ausonio et al. 2018], a further step should be geared to the detection of platforms or digital environments, immersive as well, capable of collect and manage the various data gushed from the typical complexities of the palimpsest represented by the historic buildings [Trizio et al. 20 I9c], whose stratigraphical analysis leads to the production of a significant amount of heterogeneous information to be related to the graphic (possibly three-dimensional) representation of the heritage.

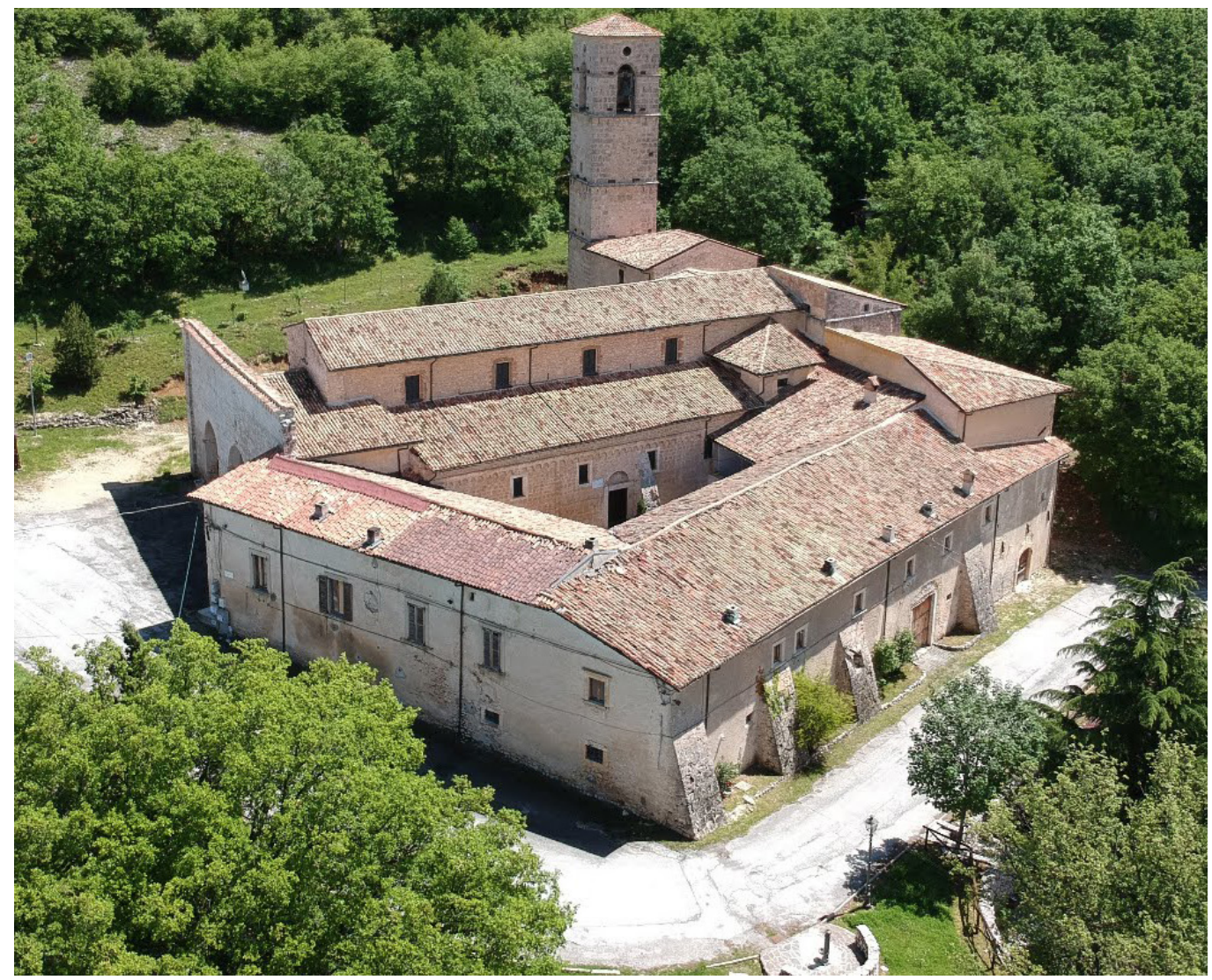




\section{The methodologies of enquiry and the instruments}

The in-depth knowledge and the appropriate documentation, even digital, of the architectural artifacts that compose our heritage are concepts often reaffirmed in many fora, becoming crucial related to those contexts in which the loss risk of the heritage, due to natural and/or anthropic events, is pronounced. Operating in the delicate moment of post-earthquake reconstruction of the L'Aquila territory, the group involved in the research study described in this paper is currently developing procedures to ensure, through digital representation, an efficient management of data derived from diagnostic, archaeological and historic-artistic analyses aimed at increasing the knowledge of the heritage and preparatory to restoration projects. To the conventional methods of investigation for the data acquisition (geometric surveys, checks on the published, analyses of archive sources and technical reports arisen from pre-existing studies etc.) are joined more exact ones targeted at deepen the knowledge (metric and typological analyses, diagnostic analyses for the state of preservation, critic study of the iconographic and ornamental apparatus, stratigraphical analyses of the masonries, etc.) by implementing a cooperation between different expertises of the researchers and professionals involved.
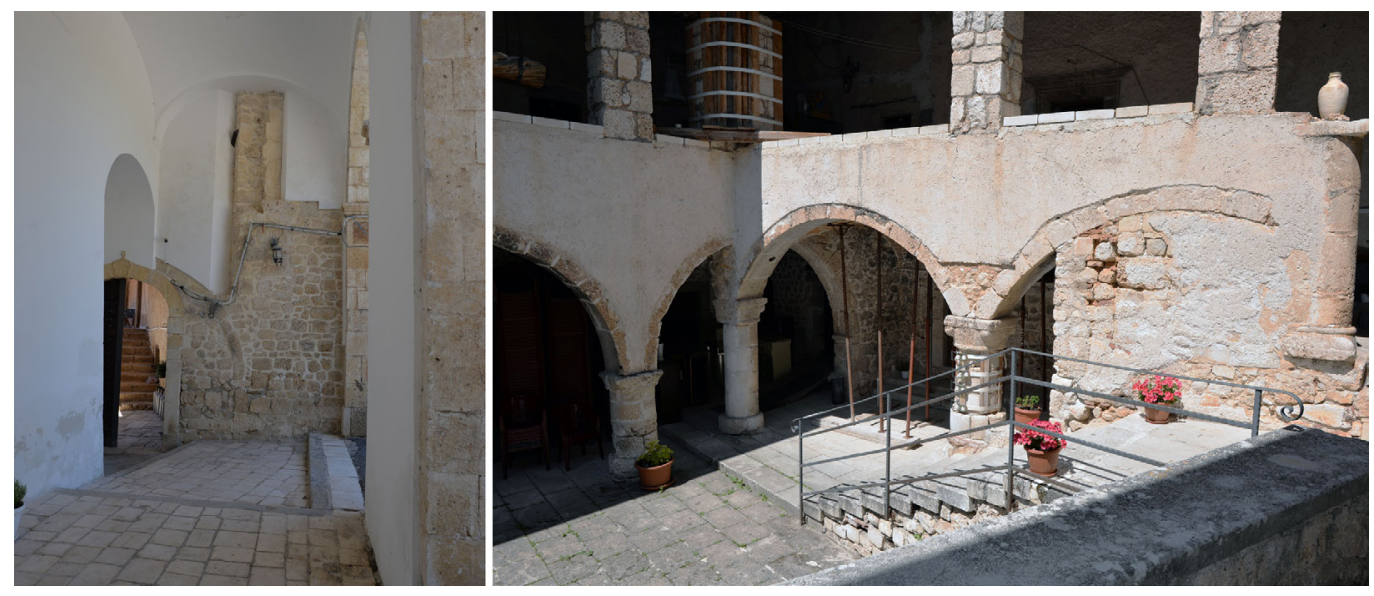

Throughout the years, particular attention has been reserved to the discussion of the issues related to $3 \mathrm{~d}$ stratigraphical analysis of archaeological and architectural contexts in digital environments through the development of models upon which have been mapped the Stratigraphic Wall Units available in *.pdf format activating the $3 \mathrm{~d}$ content [Marchetti et al. 20 I7], the implementation of 3d GIS on the basis of photogrammetric meshes [Trizio et al. $2019 \mathrm{a}$ ] and the parametric modelling of the architecture with the realization of HBIM [Continenza et al. 20 I 8; Trizio, Savini, Giannangeli 20 I8; Brusaporci et al. 20 I 8; Trizio et al. 20 I 9b]. Alongside, collaborating with researchers of the Università degli Studi dell'Aquila and independent professionals, are being investigated Virtual Reality systems for the managing of photogrammetric models with their linked information [Trizio et al. 20 I 8], for the re-enactment of disappeared or modified architectures, made visible activating timelines [Trizio et al. $2019 d$ ], along with smarter options for the realization of navigable models made with $360^{\circ}$ photos [Trizio et al. 2019c].

These latter $V R$ systems shall ensure the conservation and management of the data linked to the representation of the artifact due to the inclusion of contents (texts, images or audio) just as much as the fruition of the planivolumetric information, three-dimensional as well, thanks to links to online platforms which allow to browse the photogrammetric models and the point clouds (Sketchfab, 3DHOP etc.). 
To test the potential of this system has been undertaking the experimentation on the abbey of San Giovanni in Collimento di Lucoli, L'Aquila (fig. I), a complex with a long and stratified history which suffered damage by the 2009 earthquake that -as is not completely restored yet- is suitable for integrating the instruments of knowledge and the skills of the various professionals involved.

Fig. 3. Medieval frescoes brought to light after the restoration works of the Nineties.
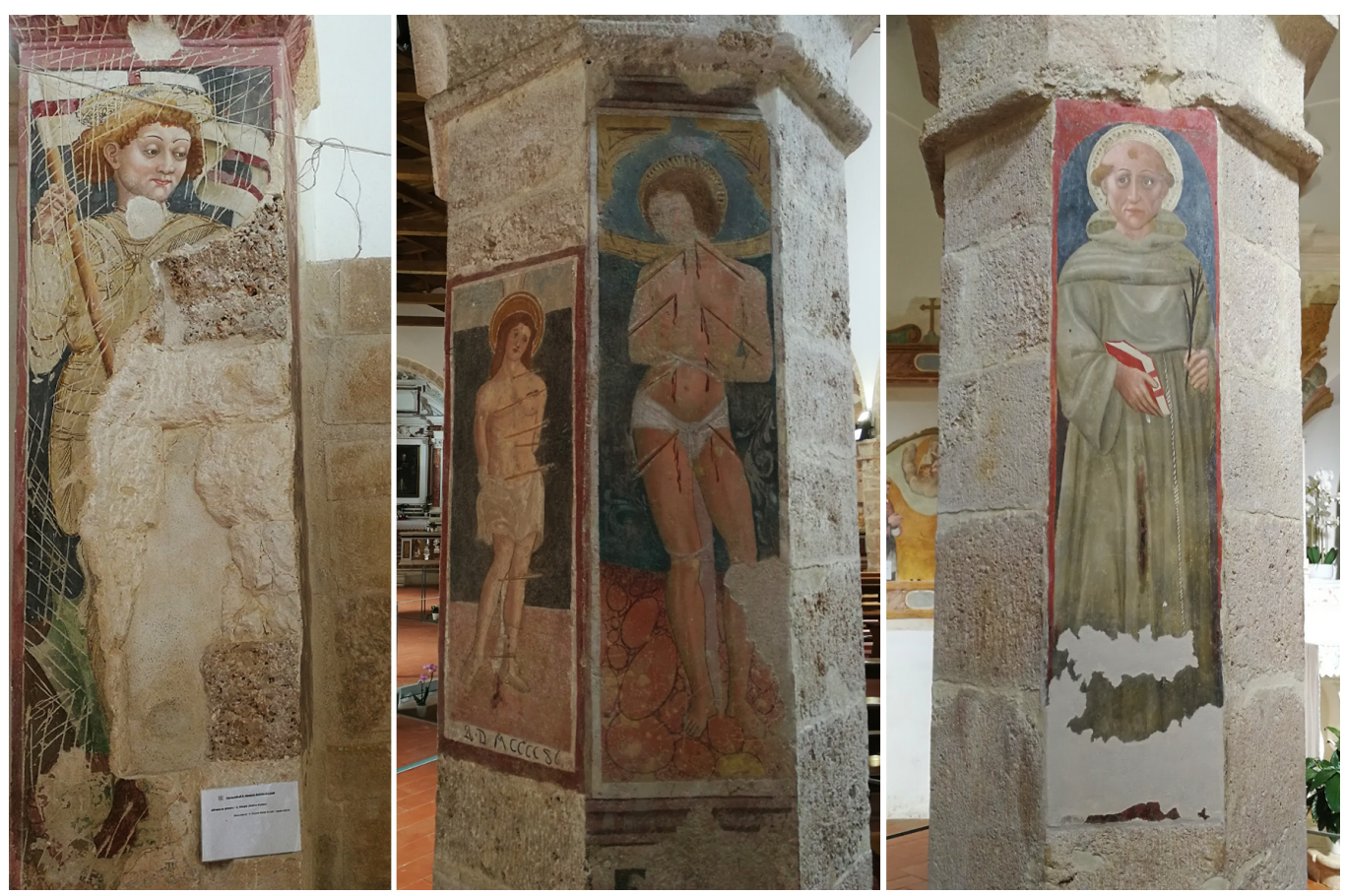

\section{The case of study: the abbey of San Giovanni in Collimento di Lucoli (AQ)}

The abbey of San Giovanni is located in the territory of Lucoli (AQ), a scattered mountain municipality with a long history interconnected with that of L'Aquila through the peculiar bound city-countryside which characterised it since its foundation. The first evidence of the abbey dates back to 1077 [Muratori 174I], just when Odorisio, Count of Marsi, founds it ex novo after his relocation in his residence in Collimento, according to the practice of expansion of the rural seignories on the territory [Marcotulli 2008]. The authority of the complex -located in a strategic point- grows over the years, as confirmed by the still-readable accuracy of the ecclesiastic and abbatial architecture, although the uninterrupted use and the continuous expansion works have significantly affected the originality of the layout. The importance of the abbey is emphasized by its role in the new foundation of the city of L'Aquila, at the hands of the angioini. As is well known the Abruzzo's capital was built by the inhabitants of the castles of the earldom to which it was granted -inside the city walls- a space called 'locale' in which settle and built, in addition to civil construction, a church for each place of origin. That of Lucoli was entitled to San Giovanni, in honor of the ancient abbey extra civitatem, and became important enough to name after one of the four quarti (quarters) in which L'Aquila is divided into, and also to play the role of capoquarto (head-of-quarter) church. Differently from the city church that begins to lose its importance giving up the collegiate title to San Marciano [Antonini 1988], the abbatial complex of San Giovanni Battista in Lucoli maintains its importance during all the Middle Ages and, in addition to interesting construction interventions realized between the XIII and the XIV century [Marcotulli 2009] is enriched with decorative works in modern era [Mancini 200 I]. 
Fig. 4. Points cloud of the architectural complex obtained with laser scanner survey.
The complex is currently composed by different overlapping and flanked buildings resulting from a series of constructive modifications, expansions, reconsiderations and restorations mainly due to historical and contemporary earthquakes (fig. 2).

A key role to the current conformation of the abbey is played by the important intervention conducted at the end of the XX century [Mancini 200I] on the abbatial church, subject of a lively scientific debate on the restoration topic [Bartolomucci 2016]. The choice of bring to light the decorative apparatus at the detriment of the architectural one, has led to the removal of the most up-to-date additions to enhance the medieval frescoes (fig. 3), some of which attributed to Andrea de Litio [lapadre 2007]. After a careful analysis of the published material produced during the '90s restoration phase [Pansa 1996; Mancini 200 I] and of the one deriving from a PhD project about light architecture started in the 2006/2007 academic year [Marcotulli 2008; 2009; 20 I0; 20II], has been prepared a cognitive analysis of the artifact through the archaeological and historic-artistic research and the analysis of the state of preservation, carried out in the field as well as remotely on the digital model obtained through the integrated survey (fig. 4).

The non-invasive diagnostic investigations were aimed to the understanding of the state of preservation of the plaster and the structures, while the archaeological analysis of the elevations was geared to the validation of the previous published, since the stratigraphic read-out resulted very difficult because of - in addition to the '90s restoration - the latest intervention carried out after the last earthquake, that have made the masonry uniform and difficult-to-read.

The data, obtained by the intersection of procedures and lexicons of the various involved disciplines (study of sources; stratigraphical analysis of the masonries; state of conservation of the walls; deterioration analysis; critical analysis of the decorative apparatus), have been analysed and re-processed with the lexicon of the design and digital representation (fig. 6). For the fruition, management and interchange of data and the enhancement of the architectural complex has been implemented a navigable digital system, a genuine virtual tour of the abbatial complex, obtained with the software 3DVista which also offers a hosting service for the visualization and sharing of the virtual product.

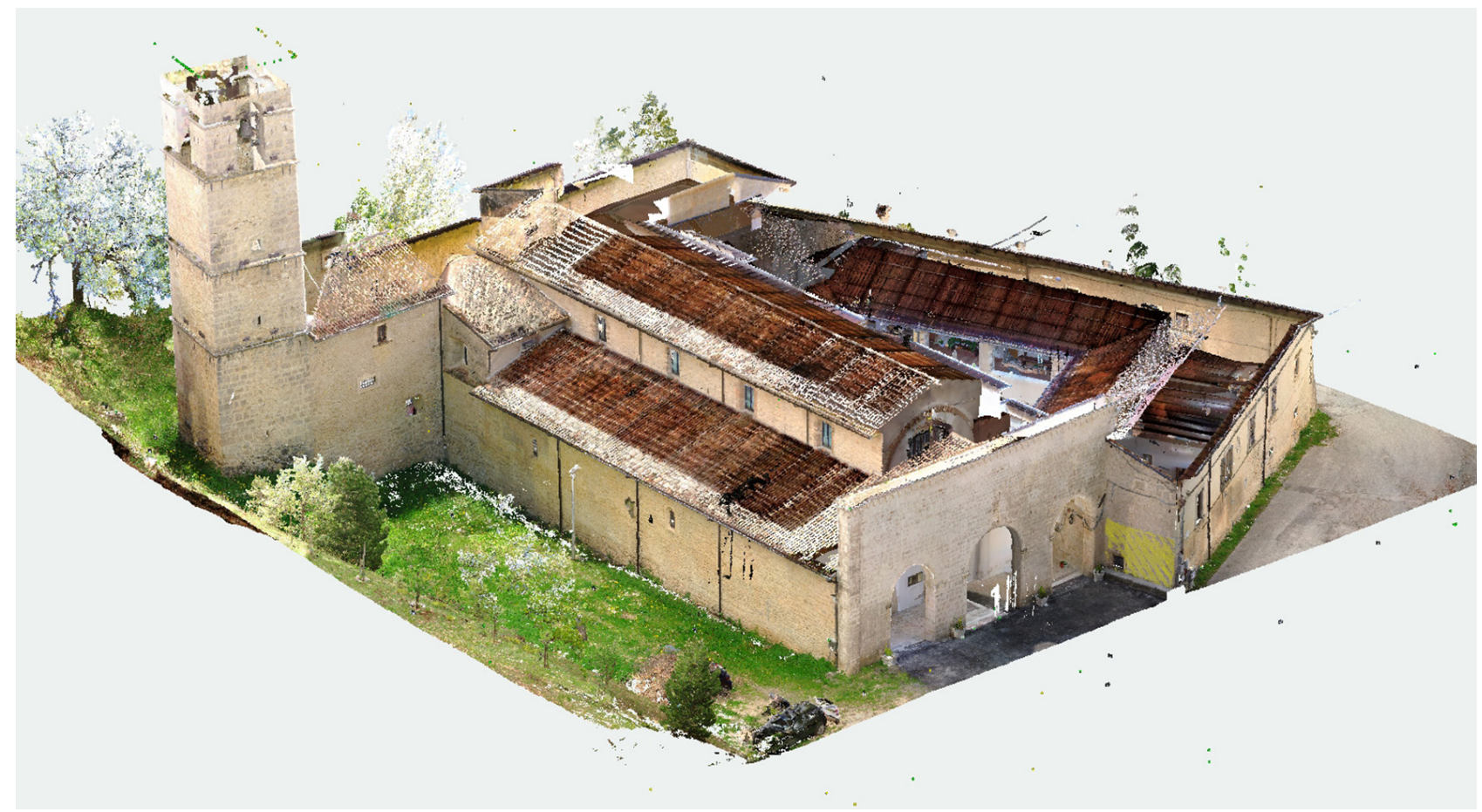




\section{From instrumental survey to VR}

The survey of the abbatial complex, obtained by the conventional integration of laser scanning (Laser scanner Faro Focus S70) and photogrammetric (Agisoft Metashape Professional I.5. I) procedures, has been implemented starting from the processing of the results of the archaeological analysis being set out in a semantic model with photo-realistic and high-resolution textures. The procedure has included the editing of the orthomosaic exported from the photogrammetric model with the mapping of the archaeological stratigraphic units, the signs of the modern restoration interventions, the visible deterioration on the masonries. The generation of a new three-dimensional model with thematic maps was made possible re-texturizing the polygonal mesh (fig. 7) into the software MeshLab (release v I.3.2), available in .pdf3D format, which allows the visualization and the querying of the model thanks to the tools of a common Adobe Reader.

Alongside, has been designed a VR environment capable of enclose and store in a single platform the scientific data and disclose them to a wider audience rising up as an instrument of enhancement of the heritage (fig. 8).

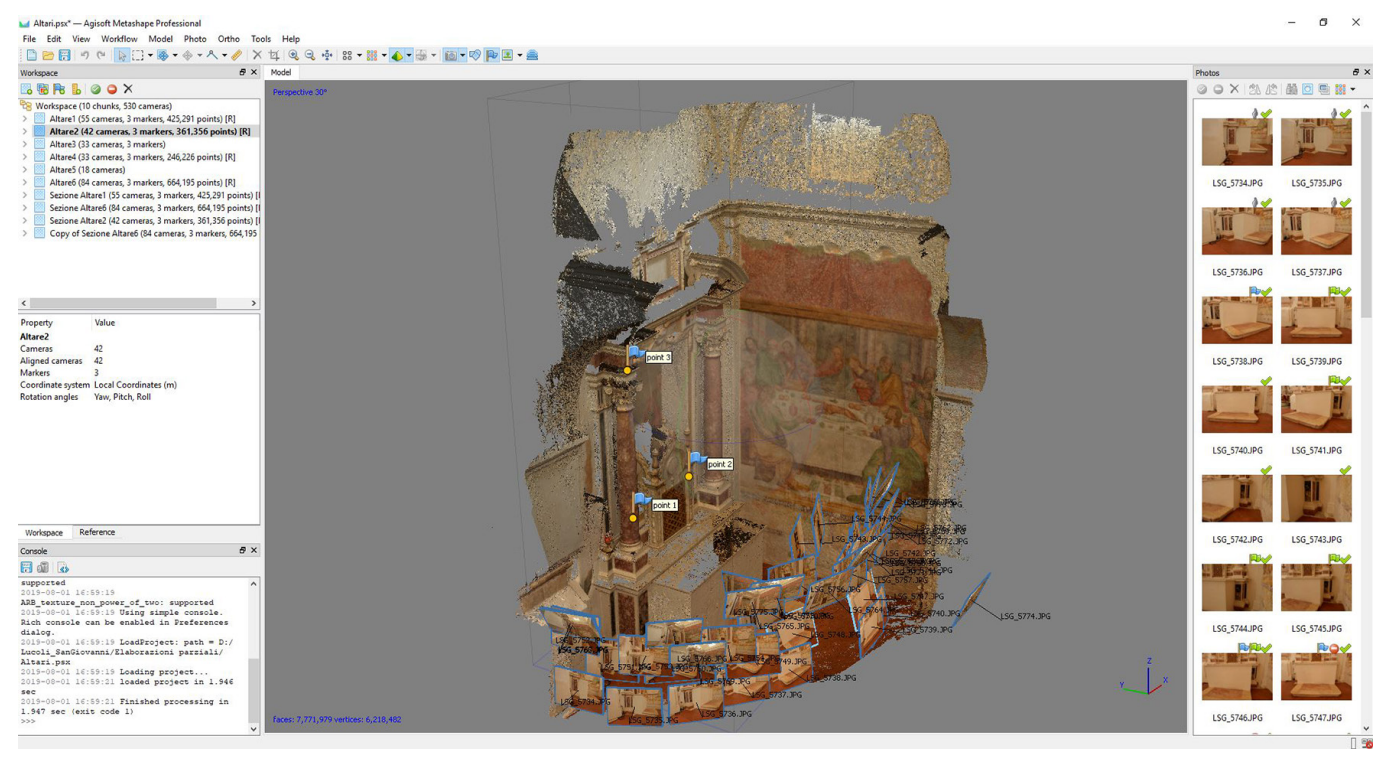

The virtual tour has been realized starting from the equirectangular images taken from each station point during the acquisition of the point clouds. The images, after been edited in their dimension with a $2 \mathrm{~d}$ graphics software, have been connected together in order to create a guided path to discover the abbey.To some points of interest (POI) located inside as outside the building have been attached the information that rework in a divulging way the results of the scientific research; thanks to textual and audio contents is possible to obtain information about time, materials, structures, environment, economics and culture linked to the story of the abbey of San Giovanni. Also inside this environment, activating appropriate hotspots, is possible to visualize the mapped masonries with the archaeological analysis, the surfaces' deterioration (figs. 8, 9) and the iconographic contents that reveal the church before and after the restoration work (fig. I I).

The realized VR system, in addition to provide the access to the information, increasing the knowledge of the cultural heritage, enlarge the accessibility to it from a wider audience through the possibility of a virtual tour, interactive and innovative. The opportunity of browsing the digital space, in desktop or in immersive mode with cardboard or VR box, puts the user on the centre stage allowing him to fully enjoy the heritage from the technic 
Fig. 6. Display of the

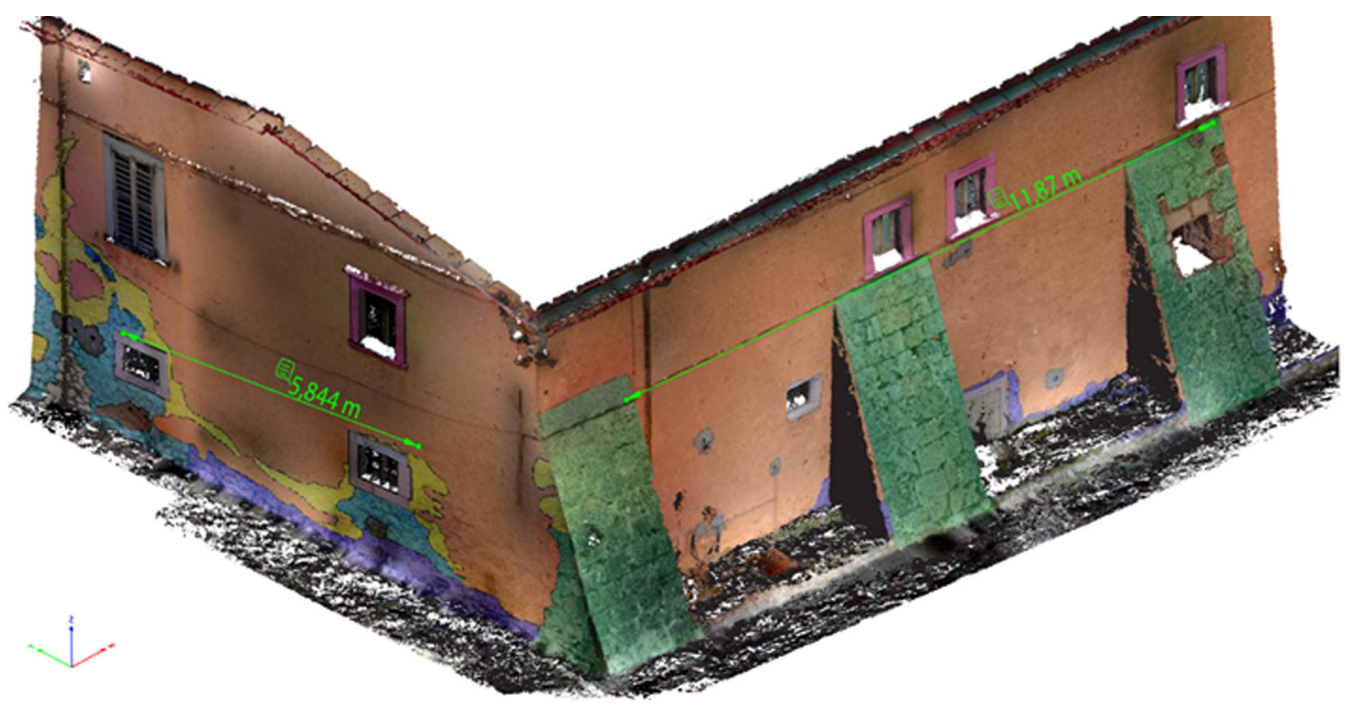

Fig. 7.Visualization of some steps of the

procedure used for

semantic model with the

Meshlab software.
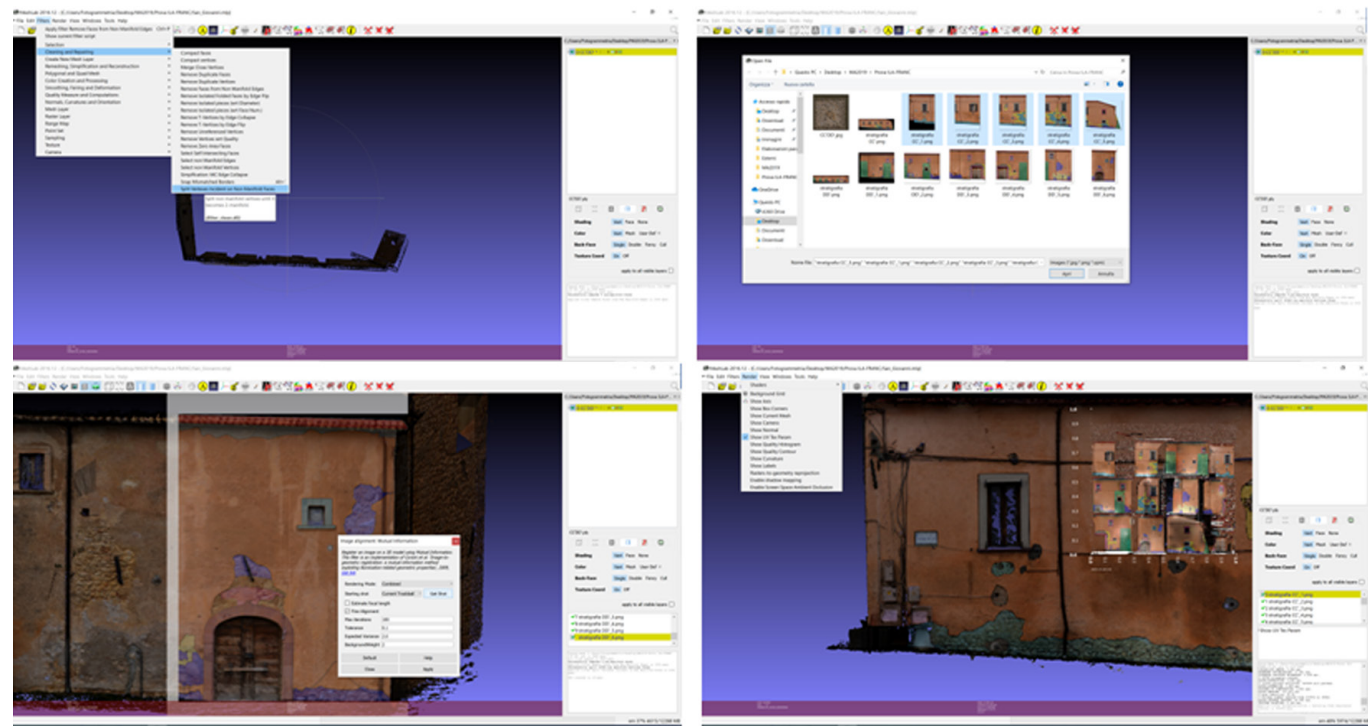
Fig. 8.VR system of the abbey for data sharing and enhancement of the architectural heritage.

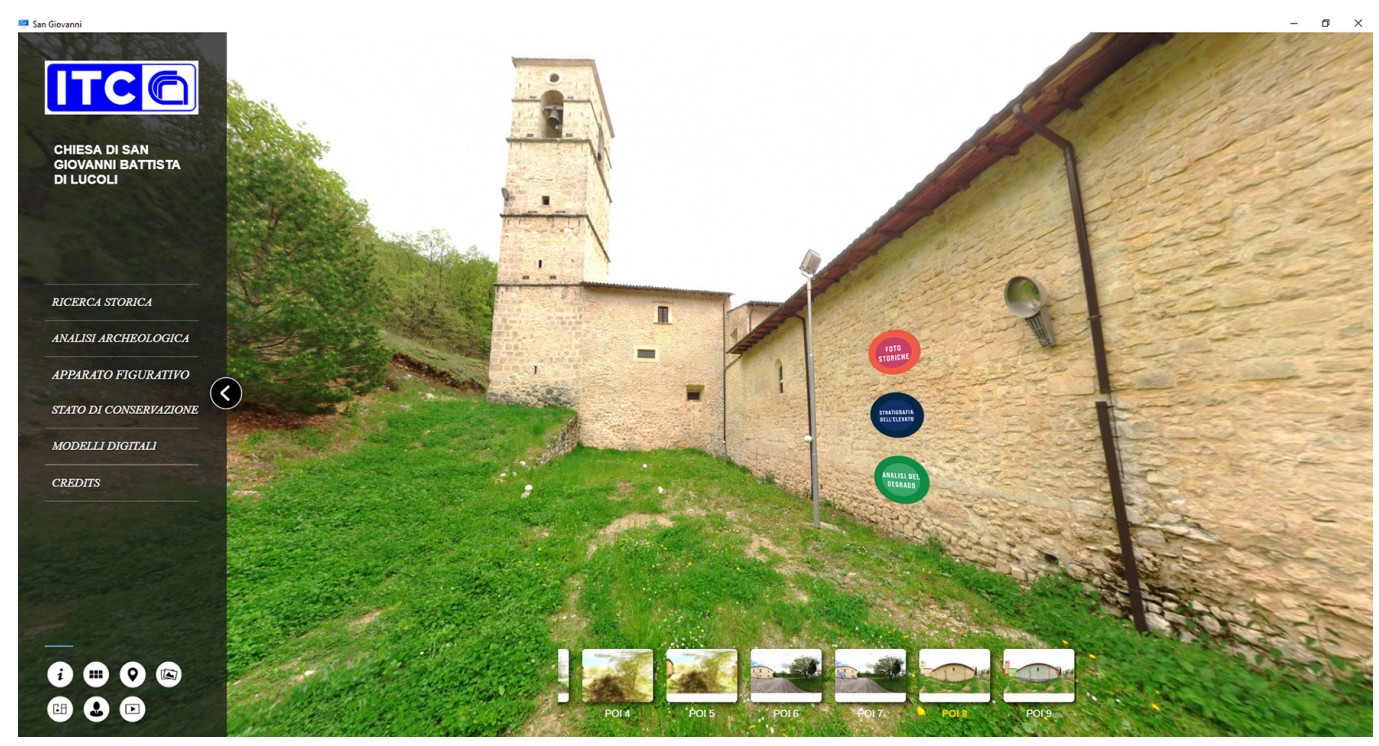

Fig. 9.VR model that allows the fruition of the results of the stratigr
analysis of the walls.

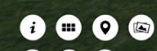 ๑) $\odot$}

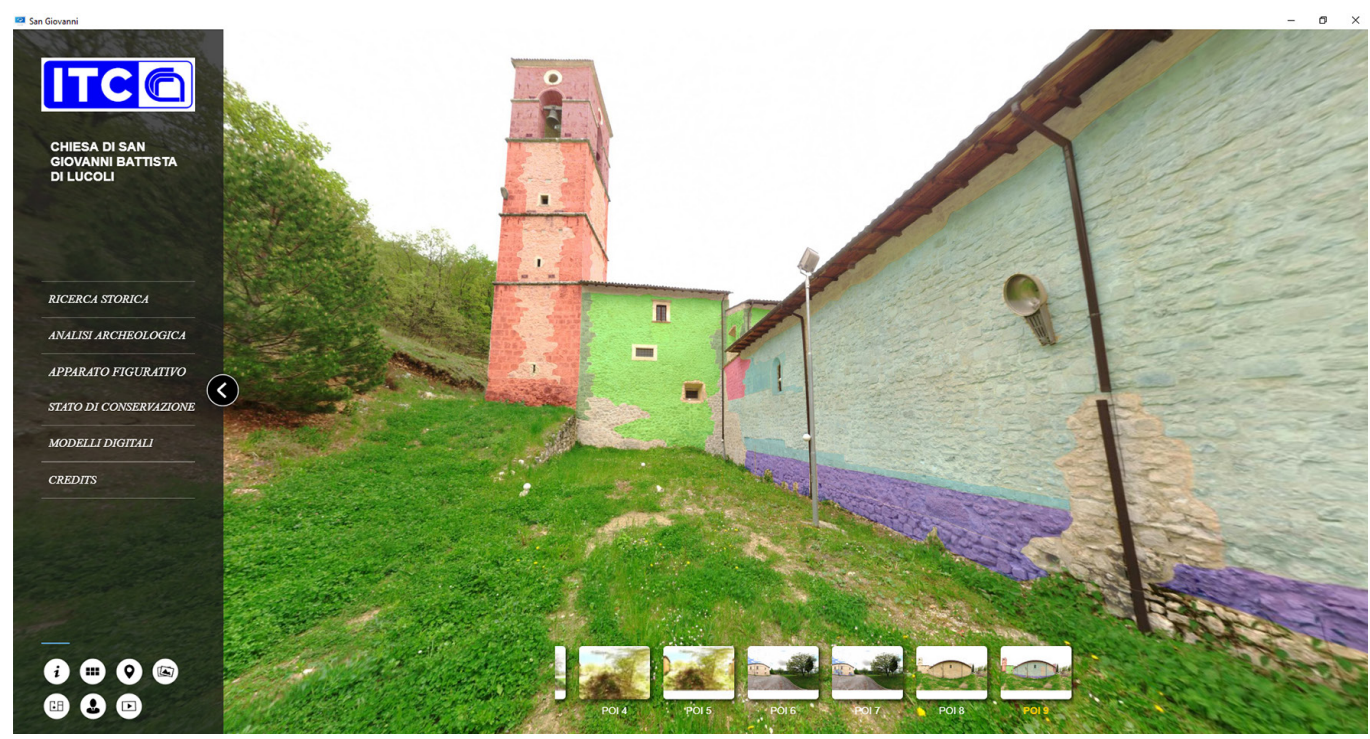

Fig. 10. VR model that allows the fruition of the results of the diagnostic analyses of the walls.

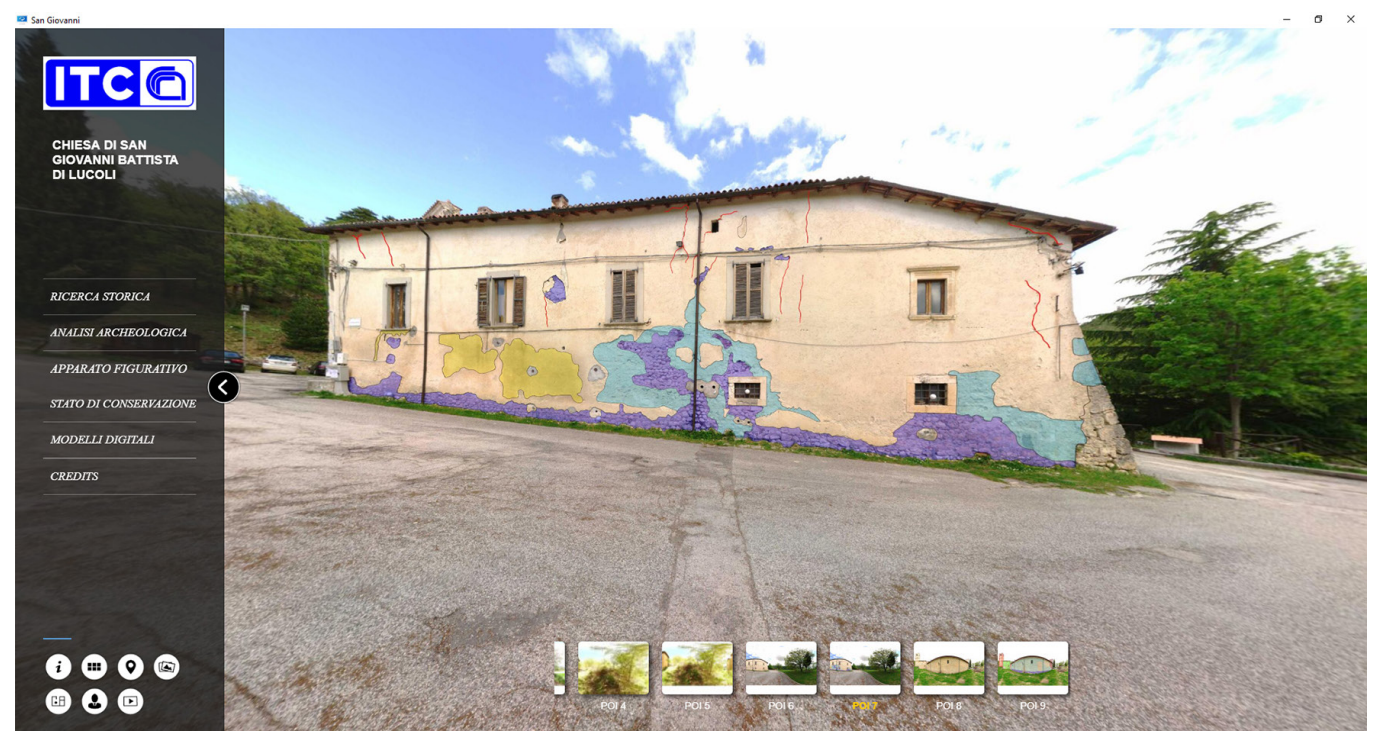


point of view (for the analysis of the artifact and the data interchange between professionals) as far as from the cultural one, simultaneously increasing the touristic offer of the territory.

\section{Conclusions and future prospects}

The various experimentations carried out on the territory in conjunction with the post-earthquake reconstruction have pointed out the potentialities of the digital representation systems for the management, analysis and scientific data interchange between the different professionals involved in the process of knowledge and recovery of the heritage.

The augmented reality, virtual reality and mixed reality systems that the research team is testing are geared to facilitate the documentation, storage and data interchange in addition to being efficient tools for the connection of the artifacts of the cultural heritage, contributing to their valorisation in order to a better touristic enjoyment. In parallel with the development of digital systems and the experimentations aimed to the using of photogrammetric models with Virtual Reality, the team is currently facing and intends to deepen the problem of the integration of parametric HBIM models with the Virtual Reality, using software dedicated to video game development, which are well suited for the representation of the Heritage [I].

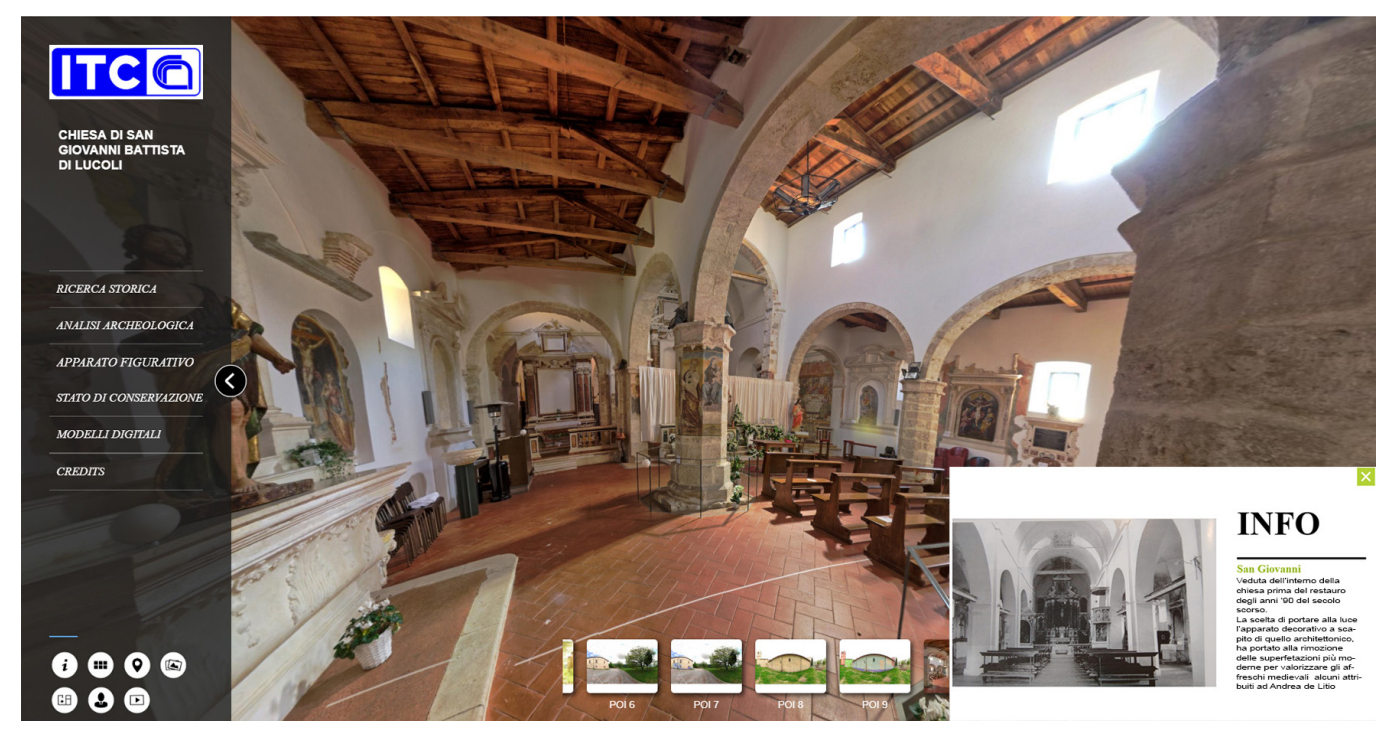

\section{Notes}

[I] Credits: Although the contribution was conceived jointly by the authors, llaria Trizio wrote paragraphs I and 2, Francesca Savini paragraphs 3 and 4. It's possible to attribute to Andrea Ruggieri the laser scanner survey of the architectural complex and the extrapolation of the equirectangular images. Tanks to Alessandro Giannangeli for the production of the photogrammetric model and to Alessio Cordisco for the implementation of the digital system usable in Virtual Reality.

\section{References}

Antonini Orlando (1988). Architettura religiosa aquilana. L'Aquila: Edizione del Gallo Cedrone.

Apollonio Fabrizio Ivan, Basilissi Vilma, Callieri Marco et. al. (2018). 3D-centered information system for the documentation of a complex restoration intervention. In Journal of Cultural Heritage, 29, 201 8, pp. 89-99.

Arrighetti Andrea, Pancani Giovanni, Gentili Marta (2019). La Pieve di Santa Maria a Buiano in Casentino. Rilievo, lettura archeologica e H-BIM delle architetture. In Archeologia dell'Architettura. XXIV, 2019, pp. I57-I76. 
Ausonio Elena, Battini Carlo, Fagandini Roberta et al. (2019). Potenzialità dei software Free e/o Open Source per la modellazione, gestione e fruizione di entità 3D. In Geomatics Workbooks, n I4, pp. 4-20. Roma: FOSS4G-it.

Bartolomucci Carla (2016). La dialettica tra eresie e ortodossie nei restauri in Abruzzo, dagli anni Sessanta all'attuale 'ricostruzione' post sismica. In Biscontin Giovanna, Driussi Guido (a cura di). Eresia e ortodossia nel restauro: progetti e realizzazioni. Atti del $32^{\circ}$ Convegno Internazionale Scienza e Beni Culturali. Bressanone, 28 giugno-I luglio 20 I 6. pp. 683-693. Venezia: Arcadia Ricerche.

Bertocci Stefano,Arrighetti Andrea, Bigongiari Marco (2019). Digital Survey for the Archaeological Analysis andthe Enhancement of Gropina Archaeological Site. In Heritage 2, 2019, pp. 848-856.

Bianconi Fabio, Filuppucci Marco (2019). La fotomodellazione per il rilievo archeologico. In Archeologia e Calcolatori, 30, 2019. pp. 205-228.

Brusaporci Stefano, Trizio Ilaria, Ruggieri Gianfranco et al. (20I8). AHBIM per l'analisi stratigrafica dell'architettura storica. In Restauro Archeologico, 27, 2018, n. I, pp. I12-131.

Continenza Romolo, Redi Fabio, Savini Francesca et al. (20 I 8). HBIM for the Archaeology of Standing Buildings: Case Study of the Church of San Cipriano in Castelvecchio Calvisio (L'Aquila, Italy). In Fogliaroni Paolo, Ballatore Andrea, Clementini Eliseo (eds). Proceedings of Workshops and Posters at the 13th International Conference on Spatial Information Theory. COSIT 2017. Lecture Notes in Geoinformation and Cartography. 3 I 5-323 pp. Cham: Springer.

Dell'Unto Nicolò, Landeschi Giacomo, Leander Touati Anne-Marie et al. (2016). Experiencing Ancient Buildings from a 3D GIS Perspective: a Case Drawn from the Swedish Pompeii Project. In Journal of Archaeological Method and Theory, 23, Issue I. pp. 73-94.

Dell'Unto Nicolò (20 I 6). Using 3D GIS Platforms to Analyse and Interpret the Past. In Forte Maurizio, Campana Stefano (eds). Digital Methods and Remote Sensing in Archaeology. Archaeology in the Age of Sensing. pp. 305-322. Cham: Springer.

Drap Pierre, Papini Odile, Pruno Elisa, et al. (2017). Ontology-Based Photogrammetry Survey for Medieval Archaeology: Toward a 3D Geographic Information System (GIS). In Geosciences, 7, 20 17, 93.

Garagnani Simone, Gaucci Andrea, Gruška Bojana (2016). From The Archaeological Record To Archaeobim:The Case Study OfThe Etruscan Temple Of Uni In Marzabotto. In Virtual Archaeology Review, 7, 5, 20 I 6, pp. 77-86.

Japadre Leonardo (2007). Guida storico-artistica dell'abbazia di san Giovanni Battista in Lucoli. L'Aquila: Japadre.

Landeschi Giacomo (20/8). Rethinking GIS, three-dimensionality and space perception in archaeology. In World Archaeology, maggio, 2018, pp. 17-32.

Mancini Renzo (200 I). San Giovanni Battista di Lucoli. Storia, cronologia, restauro. L'Aquila: Japadre.

Marchetti Alessio, Redi Fabio, Savini Francesca et al. (2017). La chiesa di San Cipriano a Castelvecchio Calvisio (AQ) nella Baronia di Carapelle: documentazione speditiva e analisi stratigrafica 3D del manufatto. In Archeologia dell'Architettura, XXII, 2017 , pp. 239-253.

Marcotulli Chiara (2008). II conte e l'abate. Incastellamento comitale e trasferimento dei poteri sui monti di Lucoli (Aq) da un'indagine di archeologia 'leggera'. In Temporis Signa, Rivista di archeologia della tarda antichita e del medioevo, III, 2008, pp. 117-139.

Marcotulli Chiara (2009). Lo viscovo e lo abbate, ... ambo con le mitre, stavano cantu lato. San Giovanni Battista di Collimento di Lucoli dentro e fuori le mura dell'Aquila: luoghi del potere e maestranze. In Giuliano Volpe, Pasquale Favia (eds). V Congresso Nazionale di Archeologia Medievale. Foggia-Manfredonia, 30 settembre-3 ottobre 2009. pp. 767-772. Firenze: Insegna del Giglio.

Marcotulli Chiara (20I0). De ecclesiis construendis: maestranze e committenti. La "rifondazione angioina" dell'Aquila e la costruzione di un'identità cittadina nella prima metà del XIV secolo. In Archeologia Medievale, XXXVII, 201 0, pp. 467-484.

Marcotulli Chiara (20 I I). Chiese, castelli e strategie 'baronali'. Le trasformazioni del paesaggio medievale abruzzese fra feudalità signorile e città fondata alla luce della ricerca archeologica: un caso di studio. In Ricerche Storiche, XLI, 20 I I, n. I, pp. I 8 I-208.

Muratori Anton Ludovico ( I74I). Antiquitates Italicae Medii Aevii, V, Mediolani, col. 817, I74I.

Pasqua Maurizio (1996). La chiesa di San Giovanni Battista a Collimento di Lucoli. Opus. In Quaderno di Architettura e Restauro, 5, 1996, pp. 25-56.

Pietroni Eva (2020). Experiencing Past, Present, and Future Urban Environments Through Digital Representation, Storytelling, and Simulation. In Forte Maurizio, Murteira Helena (eds). DIGITAL CITIES Between History and Archaeology. New York: Oxford Univerity Press. pp. I $16-125$

Trizio Ilaria, Savini Francesca, De Gasperis Giovanni et al. (2018). Siti perduti e inaccessibili: I'interpretazione del patrimonio attraverso applicazioni di realtà virtuale. In Salerno Rossella (a cura di). Rappresentazione materiale/immateriale. Atti del $40^{\circ}$ Convegno Internazionale dei Docenti delle Discipline della Rappresentazione, Milano I3- I 5 settembre 20 I 8. pp. 83 I-836. Roma: Gangemi Editore.

Trizio Ilaria, Savini Francesca, Giannangeli Alessandro (2018). The Building Information Modelling for the documentation of an archaeological site. International Workshop on Metrology for Archaeology and Cultural Heritage (MetroArchaeo 20 I8), IEEE, pp. 199-205.

Trizio llaria, Marchetti Alessio, Redi Fabio et al. (2019a). Photogrammetric survey and 3D GIS management of mesh in the integrated investigation of complex sites. The case study of the archaeological complex of the Terme di Vespasiano at Cittaducale (RI), Italy. In Inglese Carlo, Ippolito Alfonso (eds). Conservation, Restoration and Analysis of Architectural and Archaeological Heritage. Hershey, PA: IGI Global. pp. 48-80. 
Trizio Ilaria, Savini Francesca, Giannangeli Alessandro et al. (2019b). The archaeological analysis of masonry for the restoration project in HBIM. In Int. Arch. Photogramm. Remote Sens. Spatial Inf. Sci,, XLII-2/W9, pp. 7I5-722.

Trizio Ilaria, Savini Francesca, Giannangeli Alessandro et al. (2019c). Versatil tools: digital survey and virtual reality for documentation, analysis and fruition of cultural heritage in seismic areas. In The International Archives of the Photogrammetry, Remote Sensing and Spatial Information Sciences, Volume XLII-2/W 17, 2019.6th International Workshop LowCost 3D - Sensors, Algorithms, Applications, 2-3 December 2019 , Strasbourg, France. pp. 377-384.

Trizio Ilaria, Savini Francesca, De Gasperis Giovanni et al. (2019). La navigazione VR di un'opera d'arte per la narrazione di una fabbrico storica/ VR navigation of a work of art for the tale of a historical building. In Belardi Paolo (a cura di). Riflessioni. L'arte del disegno/ll disegno dell'arte. Atti del $41^{\circ}$ Convegno Internazionale dei Docenti delle Discipline della Rappresentazione, Perugia 19-21 settembre 2019. pp. 1767- 1774. Roma: Gangemi Editore.

Vecchione Alessandro, Lureau Aurelia, Callieri Marco (2019). Gestione del dato archeologico tridimensionale via web: l'esperienza con il software 3dhop. In Archeologia e Calcolatori, 30, 2019, pp. 483-486.

\section{Authors}

Ilaria Trizio, ITC, Consiglio Nazionale delle Ricerche L'Aquila, ilaria.trizio@itc.cnr.it

Francesca Savini, Consiglio Nazionale delle Ricerche, L'Aquila, francesca.savini@itc.cnr.it Andrea Ruggieri, Università degli Studi del Molise, a.ruggieri3@studenti.unimol.it

To cite this chapter. Trizio Ilaria, Savini Francesca, Ruggieri Andrea (2020). Archeologia dell'architettura e rappresentazione digitale: procedure e strumenti tra connessioni e intersezioni/Archaeology of the Architecture and Digital Representation: Procedures and Instruments between Connections and Intersections. In Arena A., Arena M., Brandolino R. G., Colistra D., Ginex G., Mediati D., Nucifora S., Raffa P. (a cura di). Connettere. Un disegno per annodare e tessere. Atti del $42^{\circ}$ Convegno Internazionale dei Docenti delle Discipline della Rappresentazione/Connecting. Drawing for weaving relationships. Proceedings of the 42th International Conference of Representation Disciplines Teachers. Milano: FrancoAngeli, pp. 282 I-2842. 